\title{
Radiative forcing from particle emissions by future supersonic aircraft
}

\author{
G. Pitari ${ }^{1}$, D. Iachetti ${ }^{1}$, E. Mancini ${ }^{1}$, V. Montanaro ${ }^{1}$, N. De Luca ${ }^{1}$, C. Marizy ${ }^{2}$, O. Dessens ${ }^{3}$, H. Rogers ${ }^{3}$, J. Pyle ${ }^{3}$, \\ V. Grewe ${ }^{4}$, A. Stenke ${ }^{4}$, and O. A. Søvde \\ ${ }^{1}$ Dipartimento di Fisica, Università L'Aquila, Italy \\ ${ }^{2}$ AIRBUS, Toulouse, France \\ ${ }^{3}$ Centre for Atmospheric Science, Department of Chemistry, University of Cambridge, Cambridge, UK \\ ${ }^{4}$ Deutsches Zentrum für Luft- und Raumfahrt, Institut für Physik der Atmosphäre, Oberpfaffenhofen, \\ 82230 Wessling, Germany \\ ${ }^{5}$ Department of Geoscience, University of Oslo, Norway
}

Received: 20 December 2007 - Published in Atmos. Chem. Phys. Discuss.: 7 March 2008

Revised: 18 June 2008 - Accepted: 18 June 2008 - Published: 25 July 2008

\begin{abstract}
In this work we focus on the direct radiative forcing (RF) of black carbon (BC) and sulphuric acid particles emitted by future supersonic aircraft, as well as on the ozone $\mathrm{RF}$ due to changes produced by emissions of both gas species $\left(\mathrm{NO}_{\mathrm{x}}, \mathrm{H}_{2} \mathrm{O}\right)$ and aerosol particles capable of affecting stratospheric ozone chemistry. Heterogeneous chemical reactions on the surface of sulphuric acid stratospheric particles (SSA$\mathrm{SAD}$ ) are the main link between ozone chemistry and supersonic aircraft emissions of sulphur precursors $\left(\mathrm{SO}_{2}\right)$ and particles $\left(\mathrm{H}_{2} \mathrm{O}-\mathrm{H}_{2} \mathrm{SO}_{4}\right)$. Photochemical $\mathrm{O}_{3}$ changes are compared from four independent 3-D atmosphere-chemistry models (ACMs), using as input the perturbation of SSA-SAD calculated in the University of L'Aquila model, which includes on-line a microphysics code for aerosol formation and growth. The ACMs in this study use aircraft emission scenarios for the year 2050 developed by AIRBUS as a part of the EU project SCENIC, assessing options for fleet size, engine technology $\left(\mathrm{NO}_{\mathrm{x}}\right.$ emission index), Mach number, range and cruising altitude. From our baseline modeling simulation, the impact of supersonic aircraft on sulphuric acid aerosol and BC mass burdens is 53 and $1.5 \mu \mathrm{g} / \mathrm{m}^{2}$, respectively, with a direct $\mathrm{RF}$ of -11.4 and $4.6 \mathrm{~mW} / \mathrm{m}^{2}$ (net $\mathrm{RF}=-6.8 \mathrm{~mW} / \mathrm{m}^{2}$ ). This paper discusses the similarities and differences amongst the participating models in terms of changes to $\mathrm{O}_{3}$ precursors due to aircraft emissions $\left(\mathrm{NO}_{\mathrm{x}}, \mathrm{HO}_{x}, \mathrm{Cl}_{x}, \mathrm{Br}_{x}\right)$ and the stratospheric ozone sensitivity to them. In the baseline case, the calculated global ozone change is $-0.4 \pm 0.3 \mathrm{DU}$, with a net radiative forcing (IR+UV) of $-2.5 \pm 2 \mathrm{~mW} / \mathrm{m}^{2}$. The fraction
\end{abstract}

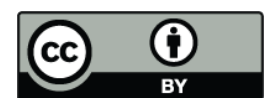

Correspondence to: G. Pitari (gianni.pitari@aquila.infn.it) of this $\mathrm{O}_{3}-\mathrm{RF}$ attributable to SSA-SAD changes is, however, highly variable among the models, depending on the $\mathrm{NO}_{\mathrm{x}}$ removal efficiency from the aircraft emission regions by large scale transport.

\section{Introduction}

The growth of the world economy is leading to a rapid expansion of aviation, due to the increasing demand for intercontinental transportation: total aviation emissions have increased and are projected to increase by $3 \%$ per year in the future (IPCC, 1999). Moreover, the desire for short travelling times increases the possibility for a future development of second generation supersonic, high speed civil transport (HSCT) aircraft, thereby introducing a considerable uncertainty about future aviation emissions. In this paper the effects of the projected subsonic aviation fleet for the year 2050 are compared to those of a mixed fleet (subsonic and supersonic aircraft), using (direct and indirect) radiative forcing calculations (RF) as a climate change index. As explained in Sect. 3 of the paper, this modeling study is based on the supersonic aircraft configurations developed by Airbus for the years 2025 and 2050 during the EU-funded project SCENIC (SCENIC, 2005; Grewe et al., 2007). A summary of the 2050 emission scenarios is presented in Table 1, with "S6" being the supersonic reference case (Mach 2.0) including aerosol emissions. It should be noted that if not specified otherwise, for the remainder of the paper we refer to scenario S6 as the reference case. Fuel consumption and $\mathrm{NO}_{\mathrm{x}}$ emission indices for the future projected subsonic fleet in the SCENIC scenarios

Published by Copernicus Publications on behalf of the European Geosciences Union. 
Table 1. Supersonic aircraft configuration and associated commercial traffic for each 2050 mixed fleet scenario. (Scenario S4 corresponds to the pure subsonic case. MTOW = maximum take-off weight, N. M. = nautical mile, RPK = revenue passenger kilometer.)

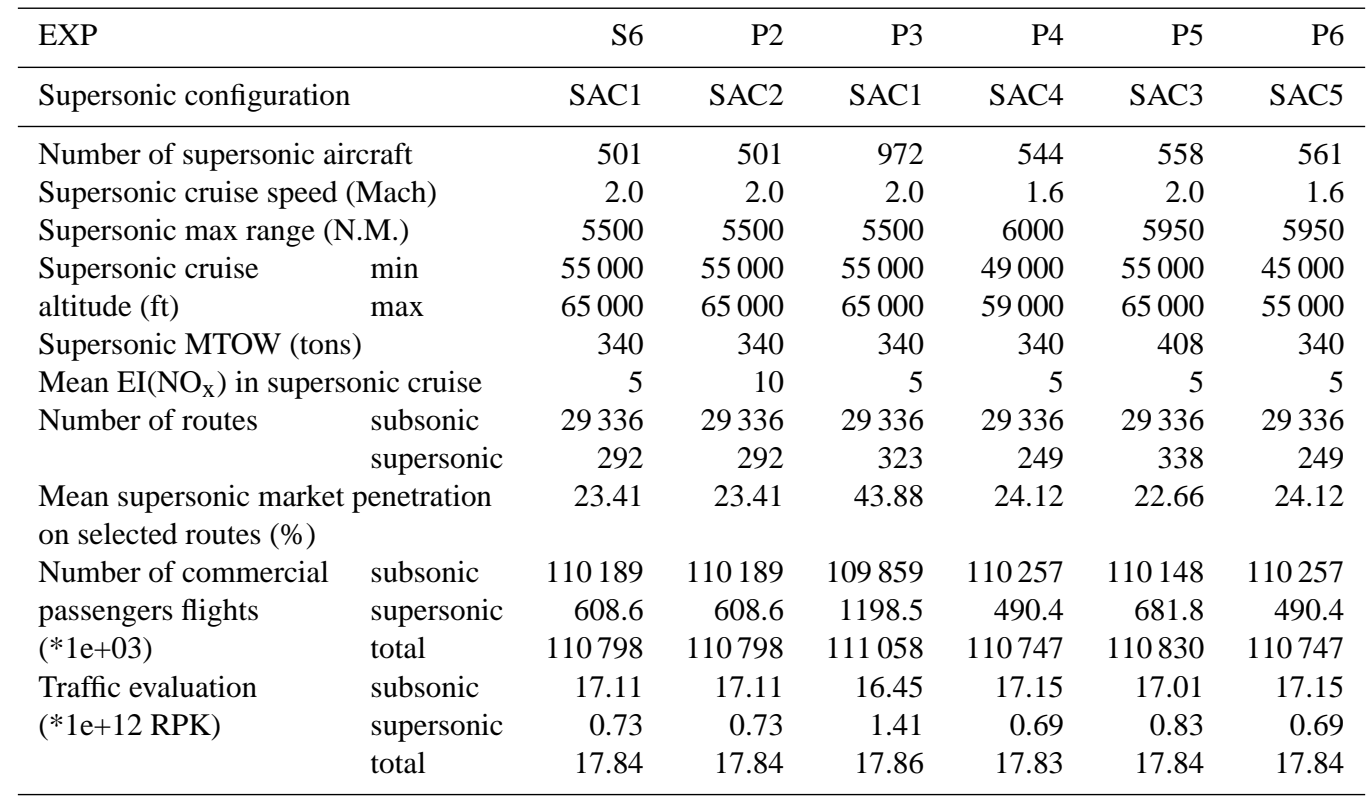

are $393 \mathrm{Tg} / \mathrm{yr}, 12.97 \mathrm{~g} / \mathrm{Kg}$ for the year 2025 and $677 \mathrm{Tg} / \mathrm{yr}$, $10.85 \mathrm{~g} / \mathrm{Kg}$ for the year 2050 (i.e. scenario S4 in Table 1), to be compared with 2000 reference values of $169 \mathrm{Tg} / \mathrm{yr}$, $12.78 \mathrm{~g} / \mathrm{Kg}$ (Grewe and Stenke, 2008). This means that the SCENIC projected average increase of fuel use is about $3.4 \%$ up to 2025 and $2.8 \%$ up to 2050 , both consistent with the $3 \%$ estimate in IPCC (1999), taking into account the projected greater efficiency of future aircraft.

Aircraft emit both gases and particles $\left(\mathrm{CO}_{2}, \mathrm{NO}_{\mathrm{x}}, \mathrm{H}_{2} \mathrm{O}\right.$, $\mathrm{CO}$, hydrocarbons, black carbon and sulphate aerosols) directly into the upper troposphere and lower stratosphere (UT/LS region), where they have an impact on the atmospheric composition. In particular, supersonic aircraft are projected to cruise at an altitude of about $19 \mathrm{~km}$, emitting directly into the stratosphere. HSCT emissions can lead to an ozone column decrease as a result of $\mathrm{NO}_{\mathrm{x}}$ and sulphate aerosol emissions, depending on the altitude of the emissions (IPCC, 1999); moreover, emitted species have longer residence times in the stratosphere, giving a different climate response compared to the subsonic case. Most of the additional radiative forcing due to HSCTs results from accumulated water vapour in the stratosphere as a direct result of emissions from aviation (IPCC, 1999; Grewe et al., 2007). The emissions of $\mathrm{NO}_{\mathrm{x}}$ into the UT/LS increases the efficiency of the catalytic $\mathrm{NO}_{\mathrm{x}}$ ozone destruction/production cycles, giving a RF which may be either positive or negative depending on the ozone perturbation distribution. Some models predict a clear crossover point between the troposphere/lower stratosphere $\mathrm{O}_{3}$ increase (below about $20 \mathrm{~km}$ ) and the midstratosphere $\mathrm{O}_{3}$ decrease (approx. $35 \mathrm{~km}$ ). Other models however have a stronger downward propagation of the midstratosphere $\mathrm{O}_{3}$ decrease, without showing a clear crossover point. In this second case the HSCT $\mathrm{NO}_{\mathrm{x}}$ emissions will always produce a negative $\mathrm{O}_{3} R F$. The uncertainty range in model predictions of the atmospheric impact of future supersonic aircraft is due to several factors: altitude of emissions, dependence on the selected HSCT scenario (Baughcum and Henderson, 1998; IPCC, 1999; Grewe et al., 2007), kinetics rates of photochemical reactions that are relevant in the lower stratosphere (JPL, 1997 and 2000; Wuebbles et al., 2003; Dessens et al., 2007), model dependent removal efficiency of supersonic aircraft emitted species from the emission regions and their transport on global atmospheric scales (IPCC, 1999; NASA, 1999; Rogers et al., 2000 and 2002).

For the aerosols we have calculated both the direct forcing (i.e. scattering and absorption of incoming solar radiation and absorption/emission of longwave planetary radiation) and indirect forcing produced by changes in the chemical species (i.e. $\mathrm{O}_{3}$ ) affected by heterogeneous chemical process on the surface of aerosol particles. Other indirect processes (for example the potential aerosol feedback on the formation of cirrus ice particles in the upper troposphere) have not been taken into account in the present work.

In Sect. 2 of this paper we give a brief description of the four chemical-transport models which are included in this intercomparison. A description of the emission data set is given in Sect. 3. In Sect. 4 we present results for black carbon (BC) and sulphate $\left(\mathrm{SO}_{4}\right)$ aerosols as simulated in the University of L'Aquila CTM (ULAQ-CTM), with appropriate model validation (Weisenstein et al., 2006; Kinne et al., 2006; Textor 
et al., 2006; Textor et al., 2007). The ULAQ-CTM is the only SCENIC model which includes an on-line aerosol microphysics code together with chemistry: a specific use of the model has been to calculate the impact of supersonic aircraft on the geometric surface area density which is then fed to the other ACMs for use in chemistry-transport calculations (Sect. 5). The atmospheric impact produced by future supersonic aircraft is discussed in Sect. 5: there we first present the radiative forcing calculations with a discussion of the role of different species $\left(\mathrm{CO}_{2}, \mathrm{H}_{2} \mathrm{O}, \mathrm{O}_{3}, \mathrm{BC}, \mathrm{SO}_{4}\right)$, before discussing the results of the chemical impact by intercomparing the different models. In Sect. 6 we summarize the main conclusions.

\section{Model descriptions}

\subsection{ULAQ-CTM}

ULAQ-CTM, from the University of L'Aquila, is a lowresolution three-dimensional aerosol-chemistry-transport model that uses a $10 \times 22.5^{\circ}$ resolution in latitude-longitude and 26 log-pressure levels, from the ground to about $0.04 \mathrm{hPa}$, with an approximate resolution of $2.84 \mathrm{~km}$. Dynamical fields are taken from the output of a spectral general circulation climate model ULAQ-GCM (Pitari et al., 2002). The chemical module contains the most important photolytic, gas phase and heterogeneous reactions relevant for stratospheric chemistry, including $\mathrm{O}_{\mathrm{x}}, \mathrm{HO}_{\mathrm{x}}, \mathrm{NO}_{\mathrm{y}}, \mathrm{ClO}_{\mathrm{x}}$, $\mathrm{BrO}_{\mathrm{x}}, \mathrm{CHO}_{\mathrm{x}}$ and $\mathrm{SO}_{\mathrm{x}}$ families. It uses reaction rates from JPL-97 and JPL-2000, the latter for the $\mathrm{NO}_{\mathrm{x}}$ cycle. Sulphur precursors in the model are $\mathrm{SO}_{2}$, OCS, DMS, $\mathrm{H}_{2} \mathrm{~S}$, and $\mathrm{CS}_{2}$, with $\mathrm{SO}_{2}$ being the most important species for the sulphur budget into the lower stratosphere, and OCS for the middle stratosphere. $\mathrm{SO}_{2}$ comes from both natural sources (volcanoes, oceans, biomass burning) and anthropogenic activities (fossil fuel burning, in situ emissions from aircraft) and is efficiently transported from the boundary layer up to the tropical tropopause layer via deep convection (Pitari et al., 2002). The model also includes the major components of tropospheric and stratospheric aerosols (sulphate, carbonaceous, dust, sea salt). The size distribution of sulphate and PSC aerosols are calculated using an interactive and mass conserving microphysical code for aerosol formation and growth. The aerosol microphysical code has been described in Pitari et al. (1993); it includes evaporation, condensation, coagulation, gravitational sedimentation, heterogeneous and bimolecular homogeneous nucleation for $\mathrm{H}_{2} \mathrm{O}-\mathrm{H}_{2} \mathrm{SO}_{4}$ (Pitari et al., 2002). Sulphate aerosols are allowed in the model to interact with carbonaceous particles, via coagulation and heterogeneous nucleation. On-line prediction of tropospheric aerosols should not only allow us to calculate realistic extinction and optical depth fields into the troposphere, but also to have a realistic treatment of the lower boundary conditions for stratospheric sulphuric acid aerosols, which in turn largely dominates aerosol mass and extinction in the middle atmosphere. The main removal processes of aerosol particles located in the troposphere (wet- dry depositions and gravitational surface sedimentation) are included. Sulphate aerosol particles are divided in 15 size bins (from $0.4 \mathrm{~nm}$ up to $10.24 \mu \mathrm{m}$ by doubling the radius) and each one of these size categories is transported separately. Sulphate and PSC aerosol surface area density fields needed for heterogeneous chemical reactions are calculated on-line using the predicted aerosol size distributions.

\subsection{SLIMCAT}

SLIMCAT, from the University of Cambridge (UCAM), is an off-line three-dimensional chemical transport model for the stratosphere, formulated on isentropic surfaces. It can be run as a multi-level model, or with just a single layer. Forcing winds from a variety of sources can be used, including ECMWF and UKMO analyses as well as GCM output. The horizontal flow, along the isentropic surfaces, is generally forced from meteorological analyses. However, the cross-isentropic transport is calculated using a radiative transfer scheme, MIDRAD. The model has been used extensively for stratospheric studies (Chipperfield et al., 1995 and 1996; Chipperfield and Pyle, 1998; Pyle et al., 1995), including investigations of the impact of supersonic aviation (Rogers et al., 2000). The spatial resolution of the model is flexible. A range of studies have been performed at a variety of resolution from T10 to T170 $(0.7 \times 0.7)$. The bottom boundary is usually taken to be the $350 \mathrm{~K}$ surface (a surface within the troposphere). Because it is formulated on isentropic surfaces, SLIMCAT should have particular advantages in the tropopause region. The default model tracer advection scheme is the second-order moments scheme of Prather (1986) which has relatively low numerical diffusion. In SCENIC the model has been used with a resolution of 18 levels, 24 latitudes and 48 longitudes.

\section{$2.3 \mathrm{E} 39 / \mathrm{C}$}

The interactively coupled chemistry-climate model E39/C from DLR, (Hein et al., 2001; Dameris et al., 2005) consists of the dynamics part ECHAM4.L39 (E39) and the chemistry module CHEM (C). E39/C is a spectral general circulation model with a vertical resolution of 39 levels from the surface up to the top layer centered at $10 \mathrm{hPa}$ (Land et al., 2002). With a particular high vertical resolution of $500-800 \mathrm{~m}$ in the tropopause region, E39/C is suitable for modeling aircraft effects (Grewe et al., 2002). Water vapour, cloud water and chemical species are advected by the Lagrangian transport scheme ATTILA (Reithmeier and Sausen, 2002; Stenke et al., 2007). E39/C includes state of the art parameterizations of small scale physical processes like convection, cloud formation or vertical turbulent diffusion. Within SCENIC the 

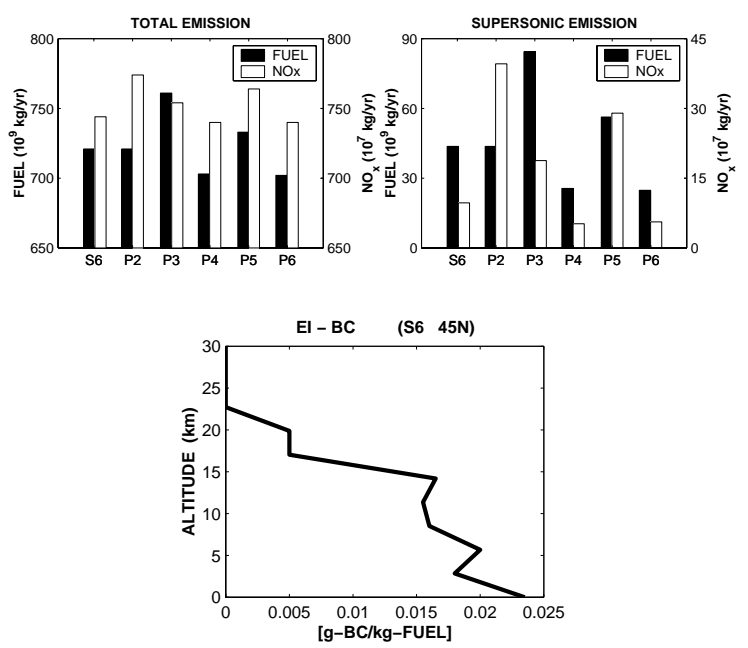

Fig. 1. Left panel: total aviation fleet emission of fuel $\left(10^{9} \mathrm{~kg} / \mathrm{yr}\right.$, left axis) and $\mathrm{NO}_{\mathrm{x}}\left(10^{7} \mathrm{~kg} / \mathrm{yr}\right.$, right axis). Right panel: as above but for supersonic fleet only. Mid-panel: black carbon emission index at $45^{\circ} \mathrm{N}$ (zonal and annual average, scenario S6, g-BC/kg-FUEL).

model is applied with a horizontal resolution of T30, i.e. dynamic processes have a horizontally isotropic resolution of $6^{\circ}$. Tracer transport, physical parameterizations and chemical reactions are calculated on the corresponding Gaussian transform grid $(3.75 \times 3.75)$. The chemistry module CHEM (Steil et al., 1998) includes stratospheric homogeneous and heterogeneous ozone chemistry and tropospheric $\mathrm{NO}_{\mathrm{x}}, \mathrm{HO}_{\mathrm{x}}$, $\mathrm{CH}_{4}, \mathrm{CO}, \mathrm{O}_{3}$ chemistry with 107 photochemical reactions, 4 heterogeneous reactions on PSCs and sulphate aerosols, and 37 chemical species. The used model version considers updates of the reaction rate coefficients (JPL, 2000). The coupled chemistry-climate model E39/C can be run in two different modes: in the off-line mode prescribed climatologies of the radiatively active gases $\mathrm{H}_{2} \mathrm{O}, \mathrm{O}_{3}, \mathrm{CH}_{4}, \mathrm{~N}_{2} \mathrm{O}$, and $\mathrm{CFCs}$ are used as input for the radiation scheme. Concentrations of chemical species as calculated by CHEM do not feedback to the dynamics component. In the on-line mode, the concentrations of the radiatively active gases as calculated by CHEM are used in the radiative calculations. For this study the off-line mode has been chosen to reduce statistical noise in the differences of two simulations.

\subsection{OsloCTM2}

OsloCTM2, from the University of Oslo (UiO), is a global three-dimensional chemical transport model, with comprehensive tropospheric and stratospheric chemistry. It is driven by meteorological data from the ECMWF Integrated Forecast System model (IFS). The advective transport is done using the highly accurate and low-diffusive second order momentum scheme (Prather, 1986). The parameterization of transport through deep convection is based on the Tiedke mass flux scheme (Tiedtke, 1989), while boundary layer mixing is treated according to the Holtslag K-profile scheme (Holtslag et al., 1990). The model is run with 40-layer meteorological data, extending from the surface to $2 \mathrm{hPa}$ (mass center at $10 \mathrm{hPa}$ ). Vertical resolution in the tropopause region varies between about $0.8 \mathrm{~km}$ in high latitudes and about $1.2 \mathrm{~km}$ in low latitudes. The horizontal resolution can be varied between T21 $\left(5.5 \times 5.5^{\circ}\right), \mathrm{T} 42\left(2.8 \times 2.8^{\circ}\right)$ and T63 $\left(1.9 \times 1.9^{\circ}\right)$. A horizontal resolution of T21 has been used for this study. Calculation of the different schemes in the model is done using operator splitting, with advective transport and chemistry being treated separately during one hour. The tropospheric chemistry scheme has been thoroughly tested in OsloCTM1 (Berntsen and Isaksen, 1997) and the tropospheric version of OsloCTM2 (Sundet, 1997). Originally, the stratospheric chemistry scheme was developed by Stordal et al. (1985) and later updated to include heterogeneous chemistry (Isaksen et al., 1990). It was also later included in OsloSCTM1 (Rummukainen, 1996; Rummukainen et al., 1990). Photodissociation coefficients are calculated from the Fast-J2 method (Brian and Prather, 2002). The numerical integration of chemical kinetics is done applying the Quasi Steady State Approximation (QSSA) (Hesstvedt et al., 1978) with a numerical time step of $5 \mathrm{~min}$. As an upper boundary, Oslo2D is used. OsloCTM2 has been validated against satellite measurements, sondes and lidar in the Norwegian Coordinated ozone and UV project (COZUV), and also during EU projects (see TRADEOFF, 2003) against satellite and aircraft measurements. The TRADEOFF validation effort is described recently by Brunner et al. $(2003,2005)$. The model has also been evaluated to some extent in Gauss et al. (2003, 2006). The OsloCTM2, although with an updated microphysics scheme, has recently been described and evaluated by Søvde et al. (2008).

\section{Aircraft emission scenarios}

This paper is based on the work undertaken during the EUproject SCENIC, using the supersonic aircraft configurations (SAC) developed by Airbus to quantify emissions produced by commercial mixed fleets, for the year 2025 and 2050 (SCENIC, 2005). For each date, one scenario for the pure subsonic case and a second for the mixed fleet case were provided. All scenarios include emissions of $\mathrm{CO}_{2}, \mathrm{H}_{2} \mathrm{O}, \mathrm{SO}_{\mathrm{x}}$, $\mathrm{NO}_{\mathrm{x}}, \mathrm{CO}, \mathrm{HC}, \mathrm{BC}$ for impact evaluations. Some of these supersonic characteristics could be modified in response to pressures linked to air traffic demand, technology evolution, economical benefits or environmental preservation. Characteristics of the supersonic scenarios are summarised in Table 1. An important underlying assumption is the utilisation of an unique market analysis for all emissions scenarios, which imply a constant number of 250 transported commercial passengers per plane. Supersonic traffic is defined by considering on each potential route its competitiveness 

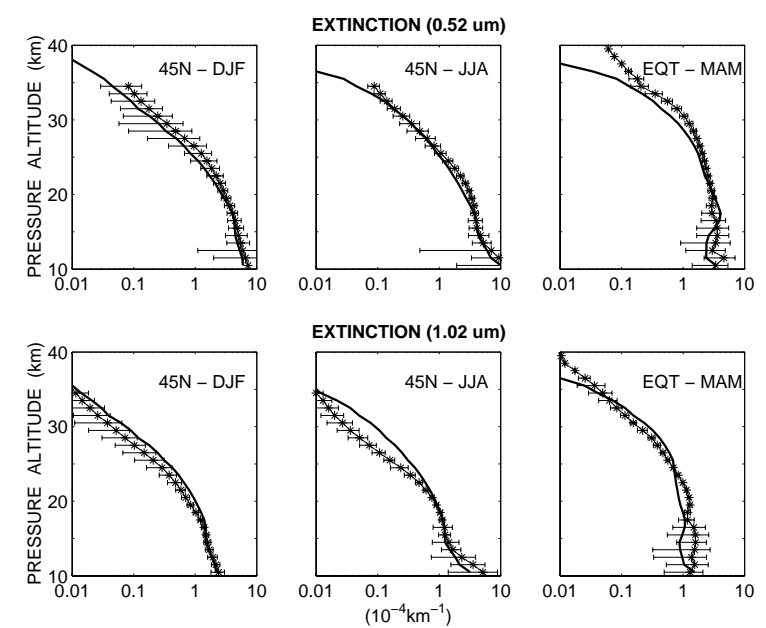

Fig. 2. Zonally averaged vertical profiles of aerosol extinction in the visible and near infrared spectrum: $\lambda=0.52 \mu \mathrm{m}$ (top panels a,b,c) and at $\lambda=1.02 \mu \mathrm{m}$ (bottom panels d,e,f) for ULAQ-CTM calculations (solid lines) and SAGE-II derived values (asterisks). Left panels (a, d) refer to wintertime averages (December, January, February) at $45^{\circ} \mathrm{N}$; middle panels $(\mathbf{b}, \mathbf{e})$ refer to summertime averages (June, July, August) at $45^{\circ} \mathrm{N}$; right panels (c, f) show averages over March-April-May at the Equator. Units are $10^{-4} \mathrm{~km}^{-1}$. Extinction values are averaged over years 2001-2002 (non-volcanic background conditions).

versus a subsonic flight. This includes time saving, minimum market penetration on the route, ticket price, and diverted distance with associated fuel consumption (over-land flights in supersonic mode have been removed for sonic bang nuisances). For this paper we consider the 2050 scenarios only. The S4 scenario provides a 3-D emissions distribution from a purely subsonic fleet; the S6 scenario provides a 3-D emissions distribution from a mixed fleet where part of commercial subsonic traffic is replaced by supersonic traffic. Aircraft-emitted particles are included in both scenarios S6 and S4, as well as in the perturbation cases (see below). The supersonic fleet in this mixed scenario fly at Mach 2.0, which implies cruise altitudes between 55 and $65 \mathrm{kft}(16.8 \mathrm{~km}$ to $19.5 \mathrm{~km})$ and cruising speed varying between 2000 and $2100 \mathrm{~km} / \mathrm{h}$.

The P2, P3, P4, P5, P6 scenarios are considered as perturbation scenarios with respect to the base case S6, in which supersonic aircraft parameters are modified to evaluate the potential environmental impact of alternative supersonic designs. The P2 scenario is representative of emissions produced by the mixed fleet including the reference HSCT aircraft, for which the mean EI $\left(\mathrm{NO}_{\mathrm{x}}\right)$ has been increased to correspond to a lower technological-level maturity; the P3 scenario is representative of emissions produced by the mixed fleet including the reference HSCT aircraft, where the demand for high-speed means of transport is increased; the
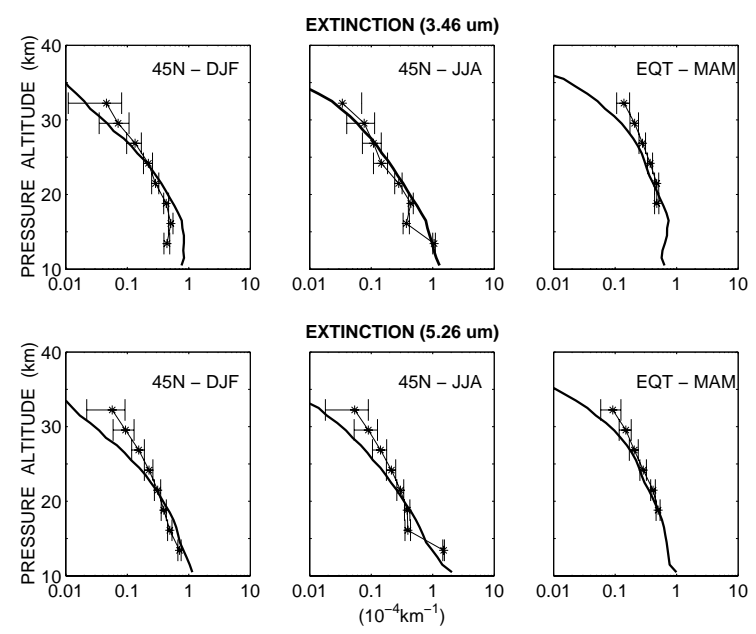

Fig. 3. Zonally averaged vertical profiles of aerosol extinction in the far infrared spectrum: $\lambda=3.46 \mu \mathrm{m}$ (top panels a,b,c) and at $\lambda=5.26 \mu \mathrm{m}$ (bottom panels d,e,f) for ULAQ-CTM calculations (solid lines) and HALOE derived values (asterisks). Left panels (a, d) refer to wintertime averages (December, January, February) at $45^{\circ} \mathrm{N}$; middle panels (b, e) refer to summertime averages (June, July, August) at $45^{\circ} \mathrm{N}$; right panels (c, f) show averages over March-April-May at the Equator. Units are $10^{-4} \mathrm{~km}^{-1}$. Extinction values are averaged over years from 1999 to 2004 (non-volcanic background conditions).

P4 scenario is representative of emissions produced by the mixed fleet including a Mach 1.6 supersonic fleet in response to other industrial objectives; the P5 scenario is representative of emissions produced by the mixed fleet including a Mach 2.0 supersonic aircraft, for which the range has been increased in response to traffic demand for longer distances; the P6 scenario is representative of emissions produced by the mixed fleet including a Mach 1.6 supersonic fleet where cruise altitude has been reduced for environmental considerations. The assumptions for the commercial passenger fleet (fixed market penetration for a given year) imply that the selection of a given supersonic configuration may change other factors, i.e. the utilisation of a Mach 1.6 configuration instead Mach 2.0 impacts the route distribution made by this supersonic fleet (some routes are removed other ones are added), the market penetration and the number of aircraft needed to transport these passengers on these routes, the flight cruise altitude, the distance flown, etc., so that the geographical emissions distribution is completely different. The percentage of the fleet passenger miles shifted from subsonic to supersonic changes with the scenario (market penetration and routes). As supersonic aircraft cannot be used on all routes, an evaluation has been made only on selected supersonic routes. The evaluation in terms of Revenue Passenger Kilometers (RPKs) for the total fleet gives: $4.1 \%$ for S6 and P2, $7.9 \%$ for $\mathrm{P} 3,3.9 \%$ for $\mathrm{P} 4$ and $\mathrm{P} 6,4.7 \%$ for $\mathrm{P} 5$. 

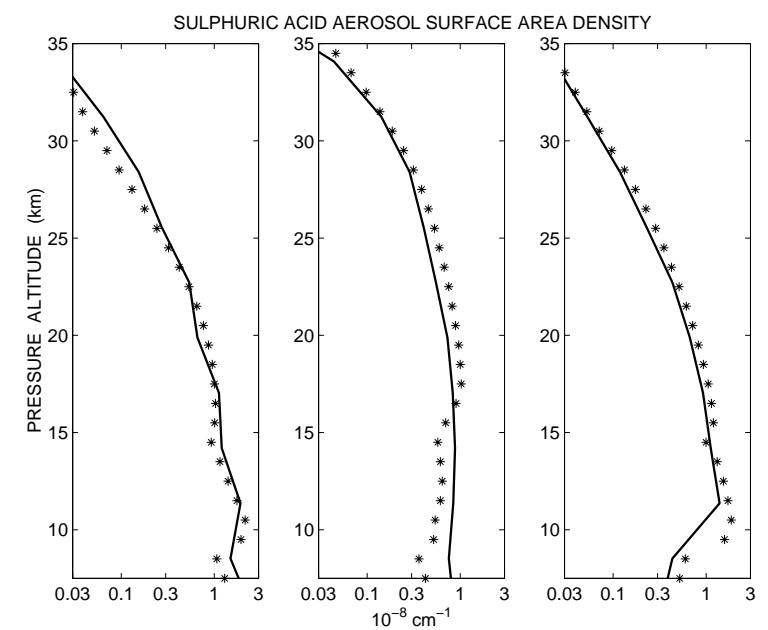

Fig. 4. Annually and zonally averaged fields of sulphuric acid aerosol surface area density: ULAQ-CTM calculations (solid lines) and SAGE-II derived values (asterisks). The three panels show averages over the following latitudinal bands: $75^{\circ} \mathrm{N}-30^{\circ} \mathrm{N}$ (left panel a); $30^{\circ} \mathrm{N}-30^{\circ} \mathrm{S}$ (mid panel b); $30^{\circ} \mathrm{S}-75^{\circ} \mathrm{S}$ (right panel c). Units are $10^{-8} \mathrm{~cm}^{-1}$. Surface area density values are averaged over the following volcanically quiet years: December 1988-November 1989 and June 1996-May 1998. ULAQ-CTM values are calculated for particles with radius larger than $0.05 \mu \mathrm{m}$ (see text).

The emission inventories are given on a resolution of $1^{\circ} \times 1^{\circ}$ in the horizontal and $1000 \mathrm{ft}$, corresponding to $305 \mathrm{~m}$, in the vertical. Fuel consumption and distance flown per year per grid cell are also included. Supersonic and total emission of fuel and $\mathrm{NO}_{\mathrm{x}}$ and EI-BC emission are shown in Fig. 1. From this figure, we see that an average emission index of $0.005 \mathrm{~g} / \mathrm{Kg}$-fuel is adopted for black carbon particles in the main emission region of supersonic aircraft (17 to $20 \mathrm{~km}$ altitude), with a log-normal size distribution peaked at $r=20 \mathrm{~nm}$. Sulphur emissions are divided in two parts: $90 \%$ of gas phase $\mathrm{SO}_{2}$ (which is then oxidized to $\mathrm{H}_{2} \mathrm{SO}_{4}$ by stratospheric $\mathrm{OH}$ ) and $10 \%$ of $\mathrm{H}_{2} \mathrm{O}-\mathrm{H}_{2} \mathrm{SO}_{4}$ ultrafine particles $(r=5 \mathrm{~nm})$.

\section{Particle perturbations}

\subsection{Validation with stratospheric aerosol observations}

ULAQ-CTM calculations of aircraft induced changes of the stratospheric surface area density of sulphate aerosols were used as input for other ACMs, in order to assess the sensitivity between models. The SCENIC emission data were interpolated onto the ULAQ-CTM grid and the model was run from 2036 to 2055 with online aerosol microphysics, for two simulations: a) the pure subsonic and b) the mixed-fleet case. Results for a) and b) were averaged from 2046 to 2055 . The initial ten years were used to provide a spin-up period for the model and the following ten years were averaged
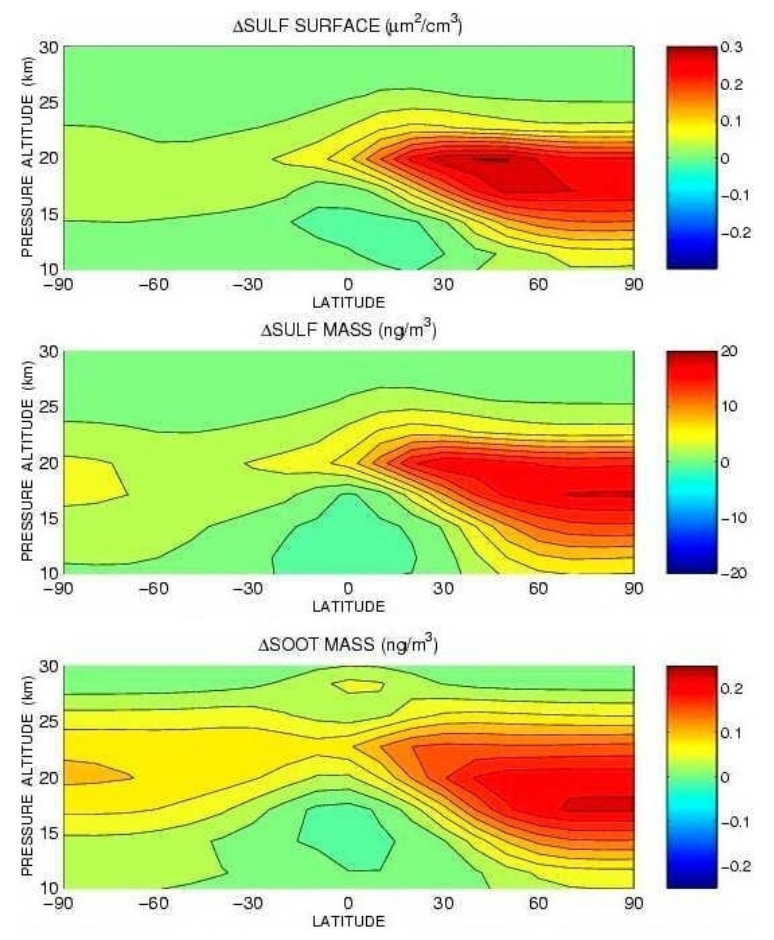

Fig. 5. Top panel: zonally and annually averaged sulphuric acid aerosol surface area density changes between simulations S6 and S4 (i.e. base case and mixed fleet minus pure subsonic case) $\left(\mu \mathrm{m}^{2} / \mathrm{cm}^{3}\right)$. Mid panel: as above, but for mass density changes $\left(\mathrm{ng} / \mathrm{m}^{3}\right)$. Bottom panel: as above, but for black carbon soot mass density changes $\left(\mathrm{ng} / \mathrm{m}^{3}\right)$.

to minimise interannual variability. The 3-D surface area density fields were then interpolated to a standard grid and made available to the other modellers in the SCENIC consortium. Table 2 summarizes the stratospheric $\mathrm{SO}_{4}^{2-}$ responses when the anthropogenic flux is $69 \mathrm{Tg}-\mathrm{S} \mathrm{yr}^{-1}$ for 2000 and is $112 \mathrm{Tg}^{-\mathrm{S} \mathrm{yr}^{-1}}$ for 2030. After 2030, the anthropogenic sulphur flux is year-by-year linearly interpolated between the IPCC-A2 projected scenarios for 2030 and 2100, the latter being $60 \mathrm{Tg}-\mathrm{S} / \mathrm{yr}$ (IPCC, 2001). This results in a 2050 anthropogenic sulphur flux of $97 \mathrm{Tg}-\mathrm{S} / \mathrm{yr}$. The natural flux is $41 \mathrm{Tg}^{-\mathrm{S} \mathrm{yr}^{-1}}$ (26 from DMS, 9.6 from non-explosive volcanoes, 5.4 from soils and biomass burning). The SAGE II derived mass, integrated above the tropopause, is $0.156 \mathrm{Tg}$ $\mathrm{S}$ with an optical depth of $15 \times 10^{-4}$ at $1.02 \mu \mathrm{m}$ and a total $\mathrm{H}_{2} \mathrm{SO}_{4}-\mathrm{H}_{2} \mathrm{O}$ mass of $0.72 \mathrm{Tg}$ (the 1979 volcanically quiet estimates reported in Kent and McCormick (1984) have been used, including a $20 \%$ correction factor necessary to take into account the 2-km layer immediately above the tropopause, as suggested by the authors). ULAQ-CTM predicts $0.151 \mathrm{Tg}$ $\mathrm{S}$ for 2000 (0.196 Tg-S for 2030), including subsonic aircraft emissions of sulphur dioxide, which agrees well with $0.156 \mathrm{Tg}-\mathrm{S}$, derived from observational data (see above). The radiative forcing reported in the last column of Table 2 is 
Table 2. Stratospheric sulphate aerosol budget: mass, optical depth and tropopause shortwave Radiative Forcing.

\begin{tabular}{lccccccc}
\hline DATA & $\begin{array}{c}\text { Natural flux } \\
\left(\mathrm{Tg}^{-} \mathrm{S} \mathrm{yr}^{-1}\right)\end{array}$ & $\begin{array}{c}\text { Anthrp. flux } \\
\left(\mathrm{Tg}-\mathrm{S} \mathrm{yr}^{-1}\right)\end{array}$ & $\begin{array}{c}\mathrm{SO}_{2} \\
(\mathrm{Tg}-\mathrm{S})\end{array}$ & $\begin{array}{c}\mathrm{SO}_{4}^{2-} \\
(\mathrm{Tg}-\mathrm{S})\end{array}$ & $\begin{array}{c}\mathrm{H}_{2} \mathrm{SO}_{4}-\mathrm{H}_{2} \mathrm{O} \\
\text { Aerosols }(\mathrm{Tg})\end{array}$ & $\begin{array}{c}\tau-1.02 \mu \mathrm{m} \\
\left(\times 10^{-4}\right)\end{array}$ & $\begin{array}{c}\text { Rad. Forcing } \\
\left(\mathrm{W} / \mathrm{m}^{2}\right)\end{array}$ \\
\hline SAGE-II & - & - & - & 0.156 & 0.720 & 15.0 & - \\
ULAQ-CTM 2000 & 41 & 69 & 25.7 & 0.151 & 0.697 & 14.8 & -0.126 \\
ULAQ-CTM 2030 & 41 & 112 & 37.0 & 0.196 & 0.946 & 21.0 & -0.179 \\
\hline
\end{tabular}

calculated using a well-tested $\delta$-Eddington code for solar radiation scattering (Pitari et al., 2002).

Validation of ULAQ-CTM results for a variety of aerosol properties was made using satellite data (SAGE II, HALOE), averaged over volcanically quiet years. A comparison of aerosol optical depths calculated by ULAQ-CTM and those obtained from SAGE II measurements is shown in Table 3: at the tropopause layer $(10-15 \mathrm{~km})$ the optical depth has a minimum in the tropics and increases toward the polar regions; the model shows an overestimation of optical depth in the Northern Hemisphere subtropical region, probably due to an unrealistic abundance of dust aerosols coming from the Sahara region. A validation of the ULAQ model calculations of tropospheric aerosol optical depth has been made in the framework of the AeroCom project (Kinne et al., 2006). A flatter latitudinal gradient is found in the model results with respect to observations in the region above $25 \mathrm{~km}$.

Extinction profiles calculated in the model for several wavelengths are compared in Figs. 2 and 3 to SAGE II and HALOE data, respectively (see also Weisenstein et al., 2006). In the stratosphere the model shows good agreement at wavelengths in the visible and near infrared, whereas an underestimation, of about a factor of 3 , is present at $\lambda=5.26 \mu \mathrm{m}$ above $30 \mathrm{~km}$. The good model performance is confirmed by the comparison of annually and zonally averaged fields of sulphate aerosol surface area density (SAD) calculated by the model with the SAGE II derived values (Fig. 4). Model values are obtained from the calculated sulphate aerosol size distribution for particles larger then $0.05 \mu \mathrm{m}$, in order to include only the contribution of optically active aerosols with geometric surface area density. The model is able to reproduce the SAD maximum (about $2 \times 10^{-8} \mathrm{~cm}^{-1}$ ) in the layer between 10 and $13 \mathrm{~km}$ poleward of $40^{\circ}$ of both hemispheres, resulting from large-scale transport accumulation (Brewer-Dobson stratospheric circulation). Differences in the polar stratosphere may be due to polar subsidence and/or to local net production processes (homogeneous nucleation in the polar vortex, nitric acid nucleation, etc.).

In conclusion, the model is successful in simulating both vertical profiles and horizontal distributions of the sulphate aerosols except for some overestimation of aerosol extinction in the upper troposphere in the subtropical regions and for a too flat high-latitude horizontal gradient above $25 \mathrm{~km}$. The

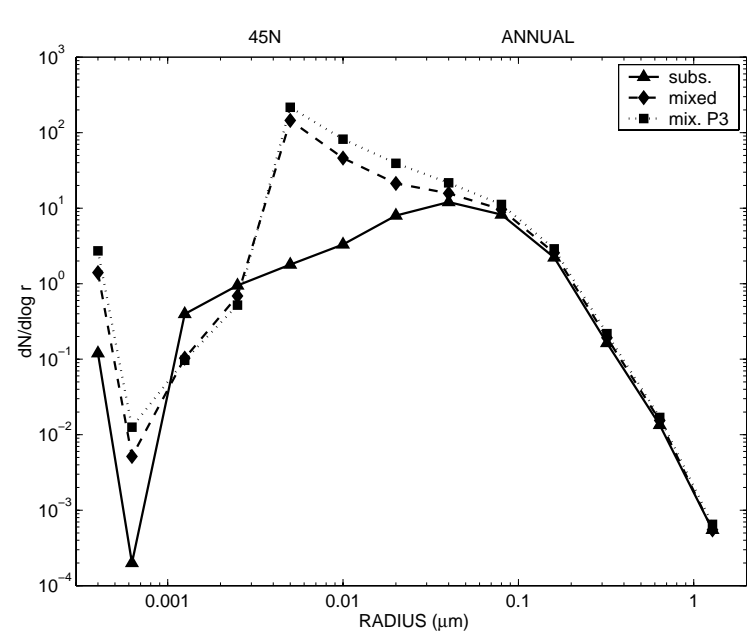

Fig. 6. Zonally and annually averaged sulphuric acid aerosol size distribution at $45^{\circ} \mathrm{N}$ and $20 \mathrm{~km}$ altitude. Solid line is for S4 (pure subsonic), dashed line for S6 (base case mixed fleet), dashed-dotted line for P3 (doubled supersonic fleet size).

stratospheric underestimation of the far infrared extinction with respect to HALOE observation may be an indication of some inconsistencies in the particle size distribution, or of an inconsistency of the imaginary part of the refraction index chosen for the calculation of the Mie scattering efficiency (Weisenstein et al., 2006).

\subsection{Mass and surface area density}

ULAQ-CTM calculated changes in sulphuric acid aerosol surface area and mass densities are shown in Fig. 5, as the result of including also supersonic aircraft emissions of sulphur; the surface area density maximum values reach $0.3 \mu \mathrm{m}^{2} / \mathrm{cm}^{3}$ in 2050 at about $20 \mathrm{~km}$ altitude in the $\mathrm{NH}$ mid-latitudes (approximately $25 \%$ of the stratospheric background values). At the same location, the sulphuric acid aerosol mass density increases by $15 \mathrm{ng} / \mathrm{m}^{3}$ (15\% of the background values). Aircraft emissions of carbon soot particles may significantly affect the mass density of carbonaceous particles above the tropopause, becoming potentially important for heterogeneous nucleation of sulphuric acid aerosols. The mass density changes of black carbon are 
Table 3. Annual mean stratospheric aerosol depth $(\lambda=0.12 \mu \mathrm{m})$.

\begin{tabular}{|c|c|c|c|c|c|c|c|c|}
\hline \multirow{3}{*}{$\begin{array}{l}\text { Latitude } \\
\text { band }\end{array}$} & \multicolumn{8}{|c|}{ Optical depth $\left(\times 10^{-4}\right)$} \\
\hline & \multicolumn{4}{|c|}{ SAGE-II } & \multicolumn{4}{|c|}{ ULAQ-CTM } \\
\hline & $10-15 \mathrm{~km}$ & $15-20 \mathrm{~km}$ & $20-25 \mathrm{~km}$ & $25-30 \mathrm{~km}$ & $10-15 \mathrm{~km}$ & $15-20 \mathrm{~km}$ & $20-25 \mathrm{~km}$ & $25-30 \mathrm{~km}$ \\
\hline $80^{\circ} \mathrm{N}-60^{\circ} \mathrm{N}$ & 18.2 & 9.5 & 1.2 & 0.18 & 16.5 & 8.6 & 2.2 & 0.55 \\
\hline $60^{\circ} \mathrm{N}-40^{\circ} \mathrm{N}$ & 16.0 & 10.0 & 3.0 & 0.46 & 18.8 & 10.0 & 3.9 & 0.75 \\
\hline $40^{\circ} \mathrm{N}-20^{\circ} \mathrm{N}$ & 10.1 & 9.3 & 4.9 & 1.00 & 20.7 & 11.3 & 5.2 & 1.00 \\
\hline $20^{\circ} \mathrm{N}-\mathrm{EQT}$ & 8.7 & 9.5 & 8.6 & 2.40 & 16.0 & 11.8 & 6.8 & 1.93 \\
\hline $\mathrm{EQT}-20^{\circ} \mathrm{S}$ & 8.4 & 10.5 & 9.6 & 2.70 & 8.1 & 8.6 & 6.6 & 2.64 \\
\hline $20^{\circ} \mathrm{S}-40^{\circ} \mathrm{S}$ & 10.6 & 12.2 & 6.0 & 1.20 & 8.8 & 9.5 & 5.2 & 1.23 \\
\hline $40^{\circ} \mathrm{S}-60^{\circ} \mathrm{S}$ & 17.0 & 13.2 & 3.6 & 0.60 & 14.7 & 8.9 & 3.9 & 0.85 \\
\hline $60^{\circ} \mathrm{S}-80^{\circ} \mathrm{S}$ & 18.9 & 9.5 & 1.0 & 0.20 & 16.2 & 8.0 & 2.3 & 0.76 \\
\hline
\end{tabular}
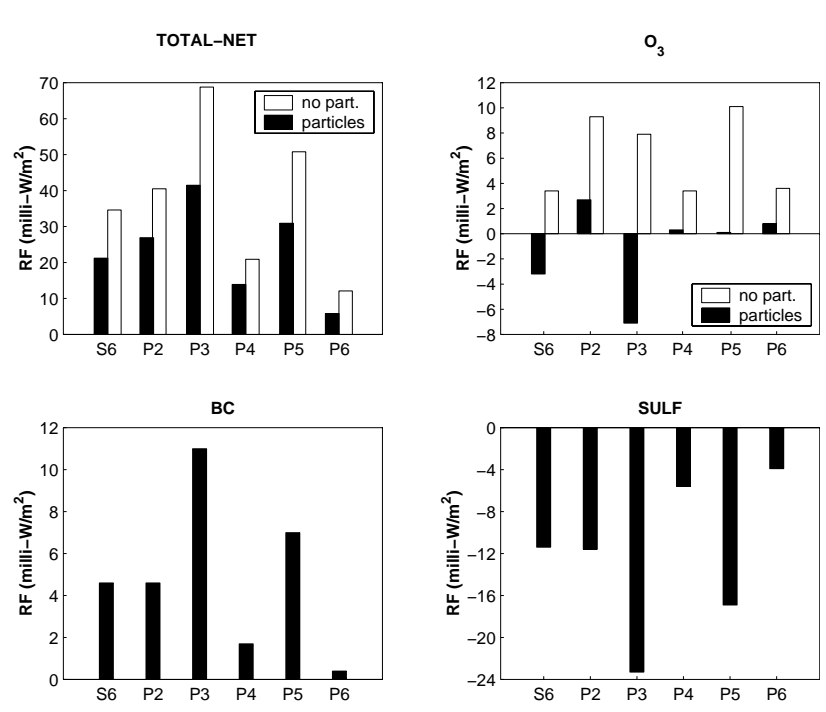

Fig. 7. Globally and annually averaged radiative forcing in year 2050 calculated with ULAQ-GCM radiative code using the ULAQCTM calculated distributions of chemical species and aerosol particles. All forcings are relative to the pure subsonic scenario S4: white filled bars refer to simulations without sulphur and BC emissions. Top left panel: net total RF. Top right panel: net ozone RF. Bottom left panel: black carbon direct RF. Bottom right: sulphuric acid aerosol direct RF. Units are $\mathrm{mW} / \mathrm{m}^{2}$.

shown in Fig. 5, bottom panel: the stratospheric increase is the direct impact of supersonic aircraft emissions (background values in the stratosphere are negligible).

Comparing these plots with those from other simulations (i.e. IPCC, 1999), it is clear that the distribution of the contours is primarily produced by large scale transport of the ultrafine particles. The absolute magnitude of the change is much less than assumed in the IPCC report for mainly three

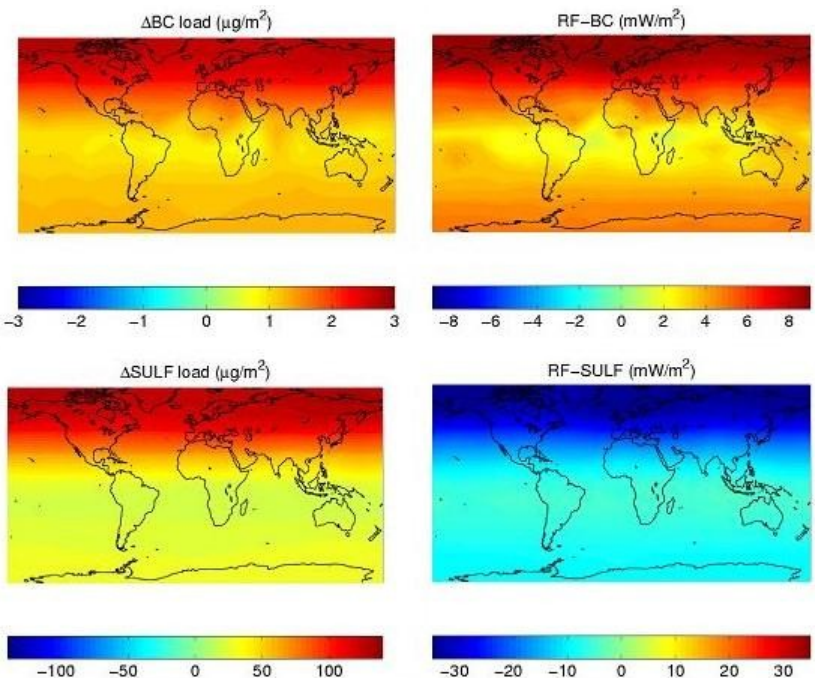

Fig. 8. Geographical distribution of annually averaged BC (top panels) and sulphuric acid aerosol (bottom panels) mass accumulated burden expressed in $\mu \mathrm{g} / \mathrm{m}^{2}$ (left side) and radiative forcing in $\mathrm{mW} / \mathrm{m}^{2}$ (right side). Results are for the base scenario S6 with respect to the pure subsonic case simulation S4. ULAQ-GCM radiative and ULAQ-CTM aerosol-transport codes.

reasons: (1) the total fuel emission here is much smaller than in the NASA-1992 emission scenarios for HSCT; (2) the assumed fraction of ultrafine particles formed in aircraft plumes is also much smaller here (10\% instead of $50 \%)$; (3) the emission height is lower, which reduces the residence time of the perturbation. The low soot emission index in the stratosphere (about $0.005 \mathrm{~g} / \mathrm{kg}$-fuel) makes the soot mass changes about 100 times smaller than the sulphuric acid mass increase. 


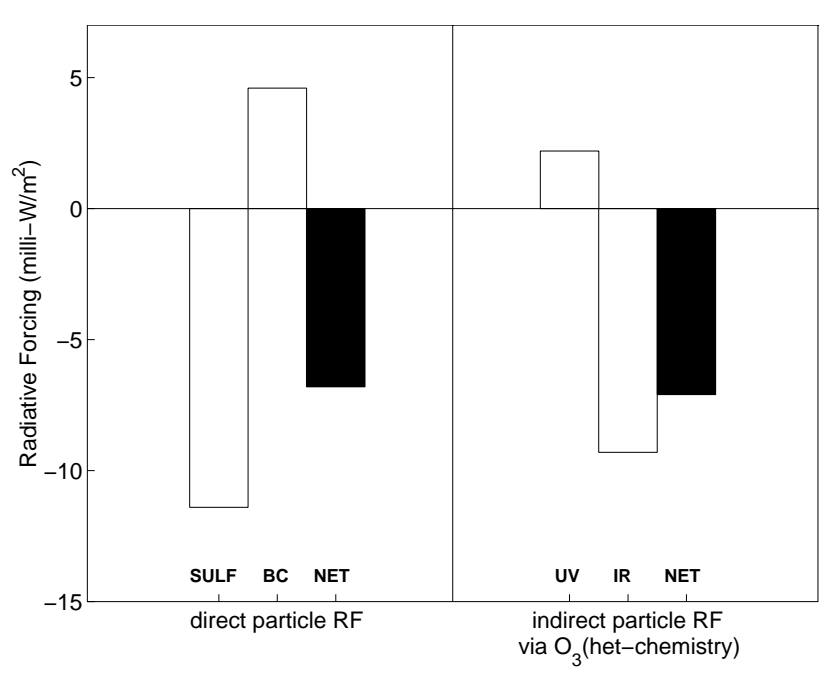

Fig. 9. Direct (left) and indirect (right) radiative forcing due to the introduction of aircraft particle emission (S6-S4). For ozone, both $\mathrm{UV}$ and IR contributions are shown. Units are $\mathrm{mW} / \mathrm{m}^{2}$. ULAQGCM radiative and ULAQ-CTM chemical-transport codes.

\subsection{Size distribution}

Supersonic aircraft emissions could perturb the global amount and the size distribution of sulphate aerosols mainly via direct plume emission of ultrafine particles $(\mathrm{r} \simeq 5 \mathrm{~nm})$. Figure 6 shows the aerosol size distribution at $45^{\circ} \mathrm{N}$ calculated with ULAQ-CTM for the subsonic fleet (S4) and the mixed fleet (subsonic+supersonic). The latter is for the baseline case (S6) and the doubled number of supersonic flights (P3). The effect of supersonic aircraft sulphur emissions is to greatly increase the number of ultrafine particles at the $5 \mathrm{~nm}$ peak due to direct particle emission in aircraft plumes. In addition, an enhanced accumulation mode is produced by the additional sulphur dioxide released on the large atmospheric scales. This additional sulphur dioxide enables sulphuric acid production following oxidation. The large increase in the ultrafine particle mode is expected to have a significant impact in the total particle surface area density available for heterogeneous chemical reactions.

\section{Atmospheric impact}

\subsection{Radiative forcing}

The University of L'Aquila general-circulation model (ULAQ-GCM) has been used to calculate the different components of the radiative forcing produced by future supersonic aircraft, with the 2050 SCENIC emission scenarios (base and sensitivity, with and without aircraft generated $\mathrm{SO}_{4}$ and $\mathrm{BC}$ particles). A $\delta$-Eddington approximation is used for evaluating solar radiation scattering/absorption in a multi-
EXPERIMENTS [S6-S4]

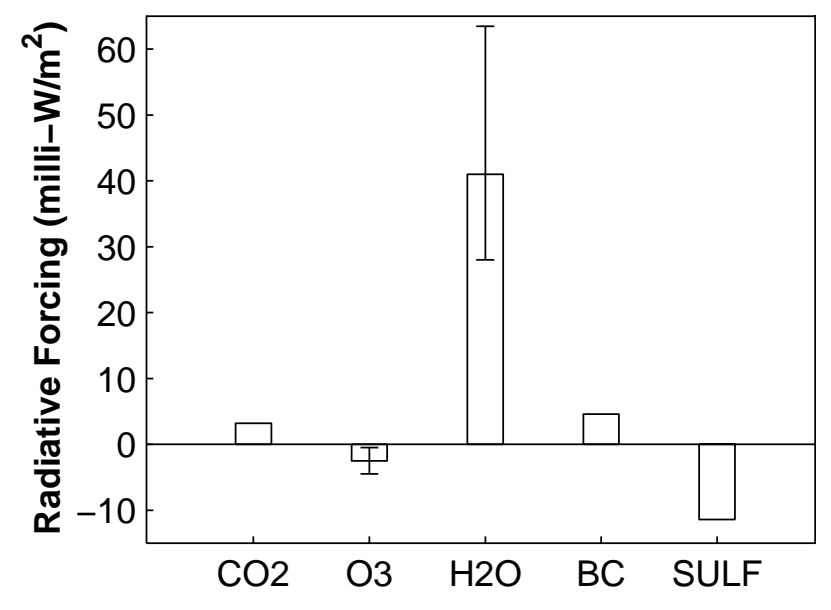

Fig. 10. Summary of (S6-S4) RF in year 2050, per component $\left(\mathrm{mW} / \mathrm{m}^{2}\right)$, calculated with the ULAQ-GCM radiative code. The uncertainty bar on $\mathrm{O}_{3}$ and $\mathrm{H}_{2} \mathrm{O}$ forcings is obtained using the ULAQ-GCM radiative code with the $\mathrm{O}_{3}$ and $\mathrm{H}_{2} \mathrm{O}$ distributions from the four independent models (SLIMCAT, ULAQ-CTM, E39/C, OsloCTM2). The single RF values obtained with $\mathrm{O}_{3}$ and $\mathrm{H}_{2} \mathrm{O}$ changes from these models, in the order above, are: -4.3 , $-3.2,-2.0,-0.3 \mathrm{~mW} / \mathrm{m}^{2}\left(\mathrm{O}_{3}\right)$ and: $63.6,28.0,40.7,31.4 \mathrm{~mW} / \mathrm{m}^{2}$ $\left(\mathrm{H}_{2} \mathrm{O}\right)$.

layer atmosphere; for the longwave spectrum, pre-calculated IR fluxes based on particle emissivity are used. A validation of the ULAQ model calculations of aerosol radiative forcing has been made in the framework of the AeroCom project (Schulz et al., 2006). $\mathrm{O}_{3}, \mathrm{H}_{2} \mathrm{O}, \mathrm{BC}$ and $\mathrm{SO}_{4}$ fields are taken from ULAQ-CTM simulations. A more detailed study of the climate impact of supersonic air traffic, looking at the different GHGs and at the sensitivity to emission scenarios, is reported in Grewe at al. (2007).

Supersonic aircraft emit water vapour directly into the stratosphere with a time scale for removal of months to years. Additional water vapour can therefore accumulate producing two effects: a direct radiative effect with a consequent influence on climate; and a chemical perturbation of stratospheric ozone via $\mathrm{HO}_{\mathrm{x}}$ radicals and polar stratospheric clouds at high latitudes. Results from baseline and perturbed experiments suggest that increasing stratospheric water vapour is the dominant HSCT climatic impact, leading to a radiative forcing which ranges from approx. 7 to $55 \mathrm{~mW} / \mathrm{m}^{2}$. The atmospheric residence time of $\mathrm{CO}_{2}$ is of the order of many decades, and as such $\mathrm{CO}_{2}$ emitted by the aircraft (proportional to the amount of fuel burnt) is well mixed in the atmosphere. The stratospheric excess of $\mathrm{CO}_{2}$ emitted by supersonic aircraft gives a RF ranging from about 2 to $6 \mathrm{~mW} / \mathrm{m}^{2}$ in the year 2050, with a date of HSCT in-service defined to 2015 (hypothesis used in SCENIC project). The net 

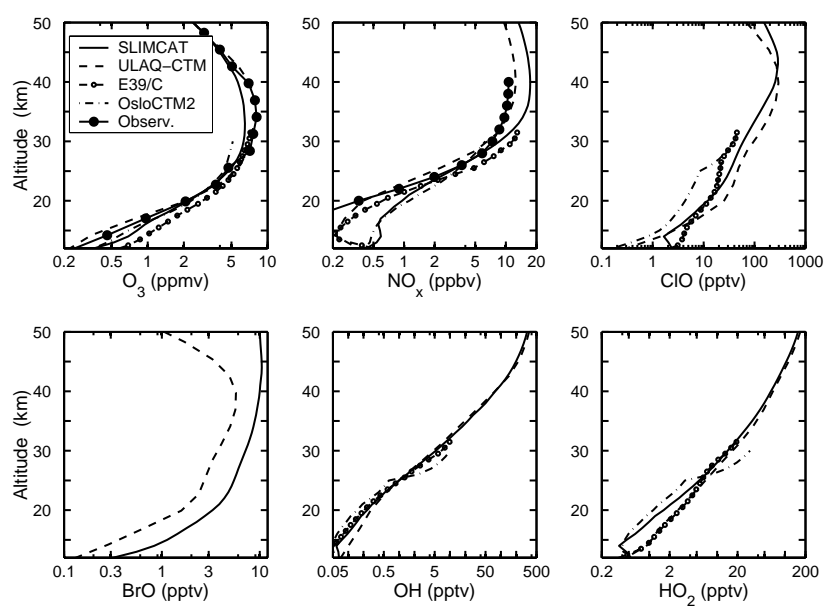

Fig. 11. Zonally and annually averaged profiles at $45^{\circ} \mathrm{N}$ for the background subsonic case $\mathrm{S} 4$. From top left: $\mathrm{O}_{3}$ (ppmv), $\mathrm{NO}_{\mathrm{x}}$ (ppbv), $\mathrm{ClO}$ (pptv), $\mathrm{BrO}$ (pptv), $\mathrm{OH}$ (pptv), $\mathrm{HO}_{2}$ (pptv). Solid, dashed, dotted and dashed-dotted lines are for SLIMCAT, ULAQCTM, E39/C and OsloCTM2, respectively. Solid dots are for $\mathrm{O}_{3}$ and $\mathrm{NO}_{\mathrm{x}}$ observations (see text).

longwave flux of $\mathrm{CO}_{2}$ is computed using the method given by Ramanathan (1976). The longwave flux and absorptance for $\mathrm{H}_{2} \mathrm{O}$ are evaluated following Ramanathan et al. (1983). A validation of the RF results coming from this code is made using the IPCC (1999) results of Forster-Haywood on one side and Ponater-Sausen on the other, after stratospheric temperature adjustment. The net $\mathrm{H}_{2} \mathrm{O}-\mathrm{RF}$ in the SCENIC baseline case is $28 \mathrm{~mW} / \mathrm{m}^{2}$ with the ULAQ model, for a total of $44 \mathrm{Tg} / \mathrm{yr}$ of fuel consumption from 2050 supersonic aircraft in scenario S6. The IPCC (1999) calculation were made with the HSCT NASA scenario (fuel consumption: $70 \mathrm{Tg} / \mathrm{yr}$ ). Scaling the ULAQ results to $70 / 44$ we get $44.5 \mathrm{~mW} / \mathrm{m}^{2}$, which is well within the range of the IPCC (1999) reference numbers of $68 \mathrm{~mW} / \mathrm{m}^{2}$ and $34 \mathrm{~mW} / \mathrm{m}^{2}$, from the calculations of Forster-Haywood and Ponater-Sausen, respectively. The calculation of the small amount of stratospheric heating produced by absorption of solar radiation by $\mathrm{H}_{2} \mathrm{O}$ and $\mathrm{CO}_{2}$ is performed following the parameterizations used by Lacis and Hansen (1974) and Vardavas and Carver (1984) for the most important $\mathrm{H}_{2} \mathrm{O}$ and $\mathrm{CO}_{2}$ bands in the visible and near-IR range.

The ozone concentration is highly variable with altitude and is controlled by atmospheric chemistry and dynamics. $\mathrm{NO}_{\mathrm{x}}$ emissions by the aircraft accelerate local photochemical production or destruction of $\mathrm{O}_{3}$. The presence of aerosols also affect the chemical balance by providing surfaces on which chemical reactions involving chlorine and bromine compounds can proceed, an effect which is enhanced at lower temperatures. The radiative forcing due to ozone is greatest when the ozone changes occur near the tropopause, in the upper troposphere and lower stratosphere. In general
Table 4a. Summary of $\mathrm{O}_{3}$ radiative forcing in year 2050 (globalannual average) for base and sensitivity experiments (RF is expressed in $\mathrm{mW} / \mathrm{m}^{2}$ ). Results from ULAQ-GCM radiative code using ULAQ-CTM species perturbations.

\begin{tabular}{ccrcr}
\hline EXP & $\Delta \mathrm{O}_{3}[\mathrm{DU}]$ & RF-IR & RF-UV & RF-NET \\
\hline S6-S4 & -0.53 & -6.8 & 3.6 & -3.2 \\
P2-S4 & -0.25 & -0.5 & 3.2 & 2.7 \\
P3-S4 & -1.07 & -14.4 & 7.3 & -7.1 \\
P4-S4 & -0.09 & -0.6 & 0.9 & 0.3 \\
P5-S4 & -0.60 & -4.9 & 5.0 & 0.1 \\
P6-S4 & -0.04 & 0.1 & 0.7 & 0.8 \\
\hline
\end{tabular}

a loss of ozone in the UT/LS region will lead to a negative radiative forcing, and an increase to a positive forcing that would tend to warm the surface-troposphere system. The precise value is a function of the assumed shape of the ozone change with altitude and of the interaction with the ultraviolet and infrared parts of the spectrum. As shown in Foster and Shine (1997) and Hansen et al. (1997), $\mathrm{O}_{3}$ in the troposphere and in the UT/LS acts mainly as a greenhouse gas, so that its interaction with longwave radiation dominates over solar UV absorption. At higher altitudes in the stratosphere the ozone interaction with incoming solar radiation becomes more important and dominates above about $30 \mathrm{~km}$ altitude. The radiative picture is even more complex since the longwave impact of some changes is rather different in the troposphere and in the stratosphere. In the first case the RF is directly due to $\mathrm{O}_{3}$ changes in the $9.6 \mu \mathrm{m}$ band (direct effect), whereas in the stratosphere $\mathrm{O}_{3}$ perturbations trigger temperature changes which then magnify the instantaneous $\mathrm{O}_{3}$ change and the longwave emissions by other greenhouse gases (indirect effect via stratospheric temperature adjustment).

Changes in upper troposphere and lower stratosphere (UT/LS) ozone concentrations due to aircraft emissions are highly spatially variable, both regionally and vertically, making assessment of global long-term trends extremely difficult. We consider the ozone radiative forcing calculations in the UV and IR regions of the spectrum separately, and summarize these results in Table 4a. The infrared contribution to the cooling rate in the $\mathrm{O}_{3}-9.6 \mu \mathrm{m}$ band has been evaluated following the assumption of cooling to space (Andrews et al., 1987); stratospheric temperatures are adjusted to the $\mathrm{O}_{3}$ perturbation. $\mathrm{O}_{3}$ absorption in the $\mathrm{UV}$ and visible wavelengths is calculated from tabulated solar fluxes and cross sections (WMO, 1985). Subsonic aircraft ozone perturbations lead to an increase in the global mean column, due to the increasing tropospheric ozone photochemical production by $\mathrm{NO}_{\mathrm{x}}$. Introduction of HSCT aircraft causes a stratospheric depletion in $\mathrm{O}_{3}$, leading to a net contribution to global $\mathrm{RF}$ which ranges from about -7 to $3 \mathrm{~mW} / \mathrm{m}^{2}$. The $\mathrm{O}_{3}-\mathrm{RF}$ (resulting from often partly compensating IR and UV contributions) is 

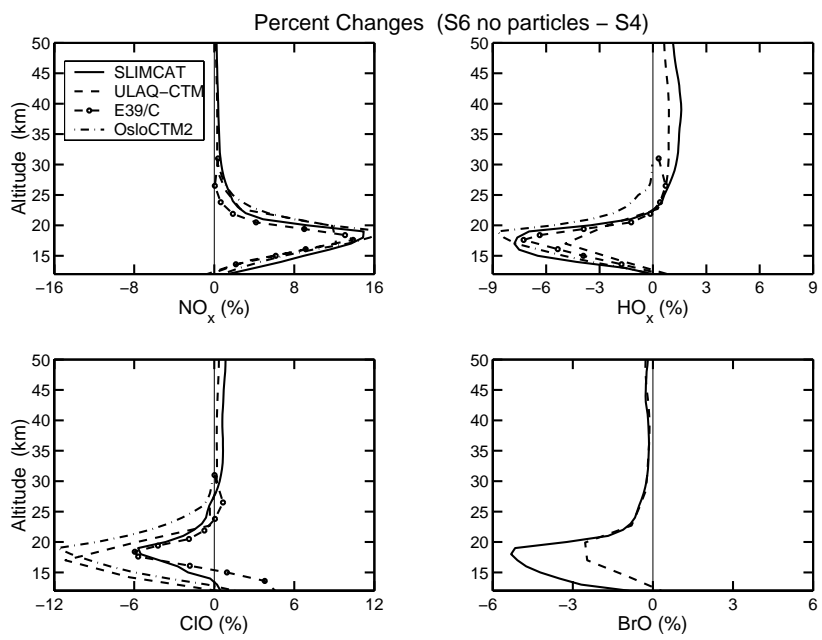

Fig. 12. Zonally and annually averaged profile changes at $45^{\circ} \mathrm{N}$ in percent for $\mathrm{NO}_{\mathrm{x}}$ (top left), $\mathrm{HO}_{x}$ (top right), $\mathrm{ClO}$ (bottom left) and $\mathrm{BrO}$ (bottom right). Changes are calculated as S6 without sulphur and $\mathrm{BC}$ emission from supersonic aircraft with respect to the pure subsonic case S4. Solid, dashed, dotted and dashed-dotted are from SLIMCAT, ULAQ-CTM, E39/C and OsloCTM2, respectively.

highly variable between scenarios, due to different changes in the profile. In addition, this RF component can be greatly model-dependent, because of different calculated $\mathrm{O}_{3}$ profile changes (see Sect. 5.2). ULAQ-CTM tends to keep the emissions more confined than other models and this favours a small positive $\mathrm{O}_{3}$ perturbation below about $20 \mathrm{~km}$ altitude (the so-called turnover point), without aircraft aerosols. Issues related to model-dependent uncertainties in the ozone perturbation are discussed in the next section.

The direct impact of aircraft sulphate aerosols on the radiative forcing is negative and produced by solar radiation scattering; in comparison direct RF in the longwave spectrum is negligible due to the small size of these particles (see Fig. 6). The parameterization adopted is that described in Lacis et al. (1992): to a good approximation the climate forcing size dependence can be described by a single parameter, the areaweighted mean radius. The calculated global mean radiative forcing from sulphate aerosol emissions caused by a partial substitution of subsonic by supersonic aircraft, ranges from about -23 to $-4 \mathrm{~mW} / \mathrm{m}^{2}$. Black carbon aerosols normally result in a positive RF since they effectively also absorb incident solar radiation (the single scattering albedo is close to 0.7 , whereas it is unity for $\mathrm{SO}_{4}$ particles). As in the case of $\mathrm{SO}_{4}$, the small size of aircraft particles produces a negligible $\mathrm{RF}$ in the longwave spectrum. The calculated global mean radiative forcing from aircraft emissions of $\mathrm{BC}$ ranges from about 0.4 to $11 \mathrm{~mW} / \mathrm{m}^{2}$. All results for radiative calculations of $\mathrm{BC}$ and $\mathrm{SO}_{4}$ aerosols for base and perturbed scenarios are summarized in Table $4 \mathrm{~b}$.
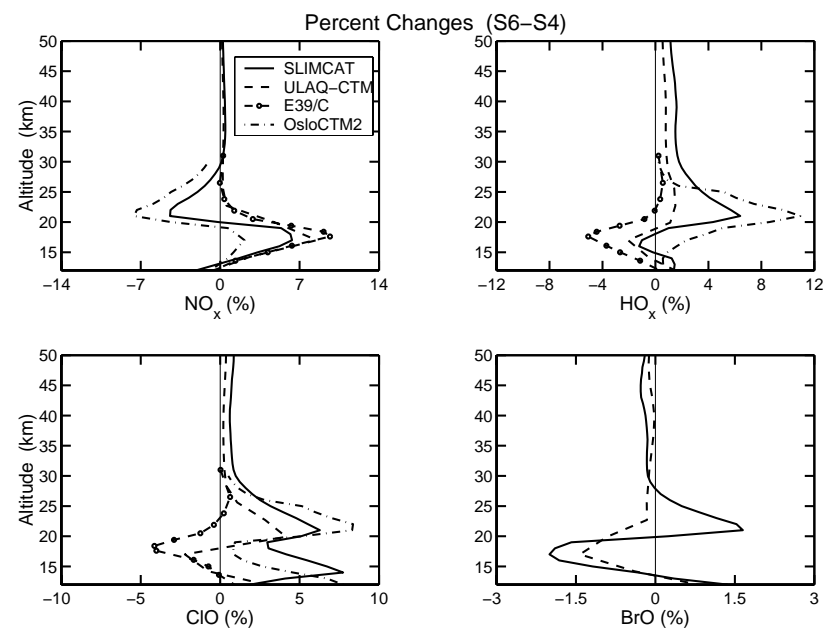

Fig. 13. As in Fig. 9, but for species profile changes calculated as S6-S4, i.e. including sulphur and BC emissions from supersonic aircraft.

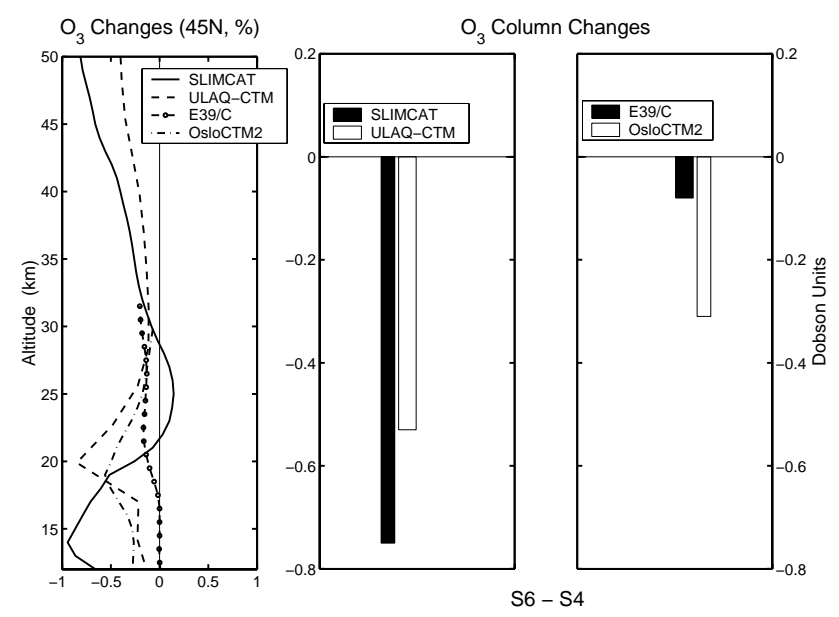

Fig. 14. Left panel: zonally and annually averaged $\mathrm{O}_{3}$ profile changes in percent at $45^{\circ} \mathrm{N}$ calculated as in Fig. 10. (i.e. S6S4). Solid, dashed, dotted and dashed-dotted are from SLIMCAT, ULAQ-CTM, E39/C and OsloCTM2. Mid panel: globally and annually averaged $\mathrm{O}_{3}$ column changes, calculated as before (i.e. S6S4). Black and white filled bars are for SLIMCAT and ULAQCTM models, respectively. Right panel: as before but for E39/C and OsloCTM2.

Figure 7 summarizes the radiative forcing components in the base and perturbed experiments as calculated with ULAQ-GCM. The calculated net climate forcing ranges from approximately 6 to $70 \mathrm{~mW} / \mathrm{m}^{2}$. The smallest forcings are those associated with the reduction in Mach number (P4) and lower cruise altitude (P6). For ozone and total net RF the change due to the introduction of aircraft particle emissions is shown, with respect to the case without particles. 
Table 4b. As in Table 4a, but for $\mathrm{BC}$ and $\mathrm{SO}_{4}$.

\begin{tabular}{ccrrr}
\hline EXP & $\Delta \mathrm{BC}\left[\mu \mathrm{g} / \mathrm{m}^{2}\right]$ & $\mathrm{RF}$-vis & $\Delta \mathrm{SO}_{4}\left[\mu \mathrm{g} / \mathrm{m}^{2}\right]$ & $\mathrm{RF}$-vis \\
\hline S6-S4 & 1.5 & 4.6 & 53 & -11.4 \\
$\mathrm{P} 2-\mathrm{S} 4$ & 1.5 & 4.6 & 54 & -11.6 \\
$\mathrm{P} 3-\mathrm{S} 4$ & 3.7 & 11.0 & 108 & -23.3 \\
P4-S4 & 0.6 & 1.7 & 26 & -5.6 \\
P5-S4 & 2.3 & 7.0 & 79 & -16.9 \\
P6-S4 & 0.1 & 0.4 & 18 & -3.9 \\
\hline
\end{tabular}

The effect of increasing the surface area density of sulphuric acid aerosols is to enhance the ozone depletion, producing an additional negative forcing, we refer to this as the aerosol indirect RF via heterogeneous chemistry. It is important to note that this conclusion is reached using ULAQ-GCM radiative code coupled to the ozone profile changes (S6-S4) predicted by ULAQ-CTM alone, since ULAQ-CTM is the only one among these models where the surface area density of sulphuric acid particles is predicted on-line together with $\mathrm{O}_{3}$, $\mathrm{NO}_{\mathrm{x}}, \mathrm{HO}_{\mathrm{x}}, \mathrm{Cl}_{\mathrm{x}}$ and $\mathrm{Br}_{\mathrm{x}}$. This allows the transport controlled accumulation of aircraft aerosols to remain consistent with the large-scale changes of the chemical species, which are a function of coupled emission-chemistry-transport mechanisms. The ozone sensitivity to the UT/LS aerosol perturbations, however, are different in other models, since the $\mathrm{O}_{3}$ response is not as spatially localized as the SSA-SAD response, but is related to that of $\mathrm{NO}_{\mathrm{x}}$. The $\mathrm{NO}_{\mathrm{x}}$ perturbation, in turn, results from a coupling of the direct aircraft emissions, large scale transport and chemical processing in the atmosphere. The latter is greatly affected by additional sulphuric acid particles. The final $\mathrm{O}_{3}$ change is connected to the net $\mathrm{NO}_{\mathrm{x}}$ perturbation and may also have a different magnitude in independent models, depending on the strength of the Brewer-Dobson circulation.

Geographical distributions of aircraft $\mathrm{BC}$ and $\mathrm{SO}_{4}$ accumulated mass burden and radiative forcing are shown in Fig. 8 as the S6-S4 difference. As expected, the mass accumulation shows a pronounced interhemispheric asymmetry, since the majority of emissions are localized in the Northern Hemisphere lower stratosphere (see also Fig. 5). The distribution of flight routes is not evident due to the long particle lifetime in the UT/LS (more than $1 \mathrm{yr}$ ) which allows efficient horizontal dynamical mixing of the tracers. Table $4 \mathrm{~b}$ indicates that there is approximately a factor of 35 difference in $\mathrm{SO}_{4}$ and $\mathrm{BC}$ burden. Peak values of local concentrations (Fig. 5) show that the $\mathrm{SO}_{4} / \mathrm{BC}$ ratio is larger and reflects the emission index ratio: $0.4 \mathrm{~g}-\mathrm{SO}_{2} / \mathrm{kg}$-fuel versus $0.005 \mathrm{~g}$ $\mathrm{BC} / \mathrm{kg}$-fuel (see Fig. 1). The smaller $\mathrm{SO}_{4} / \mathrm{BC}$ ratio in the vertically integrated column is due to the longer $\mathrm{BC}$ lifetime into the stratosphere, as the mass weighted mean radius of carbonaceous particles is much smaller than for sulphuric acid aerosols (about $20 \mathrm{~nm}$ for BC versus about $200 \mathrm{~nm}$ for $\left.\mathrm{SO}_{4}\right)$.

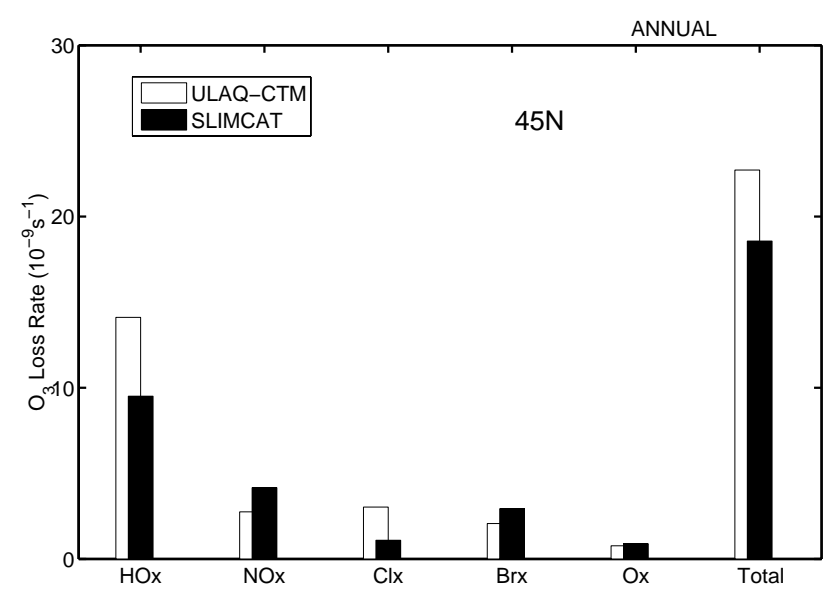

Fig. 15. Calculated annually averaged $\mathrm{O}_{3}$ loss rates $\left(10^{-9} \mathrm{~s}^{-1}\right)$ at $45^{\circ} \mathrm{N}$ for several chemical cycles in case $\mathrm{S} 4$, between 15 and $25 \mathrm{~km}$.

The total radiative forcing of $\mathrm{SO}_{4}$ and $\mathrm{BC}$ is of opposing sign due to prevailing radiation absorption from $\mathrm{BC}$ and scattering from sulphuric acid aerosols (here the single scattering albedo is close to unity). The RF reflects the S6-S4 differences in mass burden and peak values, approximately $-35 \mathrm{~mW} / \mathrm{m}^{2}$ for $\mathrm{SO}_{4}$ and $+9 \mathrm{~mW} / \mathrm{m}^{2}$ for BC.

Figure 9 shows the direct and indirect effect of the introduction of aircraft particle emissions. The globally integrated RF values in the left panel are those listed in Table 4b for S6S4: the calculated net particle forcing is $-6.8 \mathrm{~mW} / \mathrm{m}^{2}$ and can be compared with $-6.6 \mathrm{~mW} / \mathrm{m}^{2}$ obtained by subtracting the net ozone radiative forcing of $\mathrm{S}^{*}$ (without aircraft particles, $\mathrm{BC}+\mathrm{SO}_{4}$ ) from the standard $\mathrm{S} 6$ simulation (which includes aircraft particle emissions). As discussed above for Fig. 7, these globally integrated $\mathrm{RF}-\mathrm{O}_{3}$ values are obtained using ULAQ-CTM results alone which will be subtly different from those calculated from other independent models. Figure 10 shows the (S6-S4) net global RF per component. The bar indicates the range of model variability, since here $\mathrm{O}_{3}$ and $\mathrm{H}_{2} \mathrm{O}$ profile changes have been taken from all four models participating in this work (see next section). $\mathrm{H}_{2} \mathrm{O}$ and sulphate give the largest contributions to RF (23 and $-12 \mathrm{~mW} / \mathrm{m}^{2}$, respectively) (Grewe et al., 2007).

\subsection{Chemistry}

The previous section introduced the climate forcing due to ozone changes produced by aircraft emissions of $\mathrm{NO}_{\mathrm{x}}, \mathrm{H}_{2} \mathrm{O}$ and sulphate. As discussed, the magnitude and spatial distribution of ozone changes is strongly model-dependent since the transport of aircraft emissions from the source regions is dependent upon model configuration. This in turn impacts the chemically associated ozone perturbations from $\mathrm{NO}_{\mathrm{x}}$, $\mathrm{HO}_{\mathrm{x}}$ and $\mathrm{Cl}_{\mathrm{X}} / \mathrm{Br}_{\mathrm{x}}$. In addition, even a similar ozone response in a defined atmospheric region (for example the lowerstratospheric NH mid latitudes where the HSCT emissions 
are a maximum) can result in a different global signature due to variations in the model Brewer-Dobson circulation. As such, it is important to fully consider the stratospheric behavior of ozone and related chemical species in different ACMs, in order to better understand the degree of variability.

Figure 11 shows the model annually-averaged background (S4) profiles from the four participating $\mathrm{ACMs}$ for $\mathrm{O}_{3}, \mathrm{NO}_{\mathrm{x}}$, $\mathrm{ClO}, \mathrm{BrO}, \mathrm{OH}$ and $\mathrm{H}_{2} \mathrm{O}$. A comparison is made with climatological $\mathrm{O}_{3}$ values and $\mathrm{NO}_{\mathrm{x}}$ from 1993 HALOE data (NASA, 1999). All models show consistent agreement with the observations although SLIMCAT and OsloCTM2 models predict higher $\mathrm{NO}_{\mathrm{x}}$ values below $23 \mathrm{~km}$. Some caution should however be used for the $\mathrm{NO}_{\mathrm{x}}$ observations at these altitudes, since $\mathrm{NO}_{\mathrm{x}}$ values in 1993 were still influenced by Pinatubo aerosols, which effectively converted $\mathrm{NO}_{\mathrm{x}}$ into $\mathrm{HNO}_{3}$. In addition, it should be taken into account that models are run for year 2050 chemical conditions, with increased $\mathrm{N}_{2} \mathrm{O}$ and hence $\mathrm{NO}_{\mathrm{y}}$. A more detailed model validation using satellite observations is discussed in SCENIC (2005).

Perturbations of the chemical families directly affected by supersonic aircraft emissions are presented in Figs. 12-13 (Fig. 12 does not include the effect of aircraft emitted sulphuric acid aerosols and black carbon). All models consistently show a $\mathrm{NO}_{\mathrm{x}}$ peak $\left(\mathrm{NO}+\mathrm{NO}_{2}\right)$ at $18 \mathrm{~km}$ with a magnitude ranging between 12 and $16 \%$, together with a continual decrease of the perturbation towards zero at altitudes of approximately 12 and $30 \mathrm{~km}$. As expected, the $\mathrm{HO}_{\mathrm{x}}$ change $\left(\mathrm{OH}+\mathrm{HO}_{2}\right)$ is anti-correlated with $\mathrm{NO}_{\mathrm{x}}(-8$ to $-4 \%$ at $18 \mathrm{~km}$ ), since the $\mathrm{OH}$ sink from the $\mathrm{OH}+\mathrm{NO}_{2}+\mathrm{M}$ reaction forming $\mathrm{HNO}_{3}$ dominates over the additional $\mathrm{OH}$ source from direct water vapour emissions by aviation. It should be noted that for the two models with a good vertical resolution of the whole stratosphere (SLIMCAT, ULAQ-CTM) a clear $\mathrm{HO}_{\mathrm{x}}$ increase is predicted above $22 \mathrm{~km}(\sim+1.5 \%$ at $30 \mathrm{~km}$ altitude). Here the additional $\mathrm{H}_{2} \mathrm{O}$ source becomes more important than the $\mathrm{NO}_{\mathrm{x}}$ induced sink of $\mathrm{HO}_{\mathrm{x}}$. As with $\mathrm{HO}_{\mathrm{x}}$, $\mathrm{ClO}$ and $\mathrm{BrO}$ are also anticorrelated with $\mathrm{NO}_{\mathrm{x}}$. The $\mathrm{ClO}$, $\mathrm{BrO}$ sinks are due to formation of chlorine and bromine nitrates respectively $\left(\mathrm{ClO}+\mathrm{NO}_{2}+\mathrm{M}\right.$ and $\mathrm{BrO}+\mathrm{NO}_{2}+\mathrm{M}$, forming $\mathrm{ClONO}_{2}$ and $\mathrm{BrONO}_{2}$ ).

Inclusion of aerosol perturbations due to sulphur emissions by aviation has a significant impact on the results discussed above. Under these conditions the $\mathrm{NO}_{\mathrm{x}}$ perturbation is the net result of two opposing effects: a) a direct increase due to aircraft emissions; and b) a decrease due to enhanced chemical conversion into $\mathrm{HNO}_{3}$ via heterogeneous chemical reactions of $\mathrm{N}_{2} \mathrm{O}_{5}$ and $\mathrm{BrONO}_{2}$ on sulphuric acid particles (other heterogeneous chemical reactions are less important at mid-latitudes). Figure 13 suggests that this balance may change with altitude, being a function of aircraft $\mathrm{NO}_{\mathrm{x}}$ emissions, aerosol lifetimes and accumulation, and $\mathrm{NO}_{\mathrm{x}}$ partitioning $\left(\mathrm{N}_{2} \mathrm{O}_{5}\right.$ increases with altitude). The peak in the $\mathrm{NO}_{\mathrm{x}}$ increase discussed in Fig. 12 is reduced by a factor of 3 (even more in OsloCTM2) due to the inclusion of aerosols, and above $20 \mathrm{~km}$ the $\mathrm{NO}_{\mathrm{x}}$ decrease prevails in OsloCTM2 and
SLIMCAT. In ULAQ-CTM the net $\mathrm{NO}_{\mathrm{x}}$ perturbation is always positive, although smaller than in Fig. 12. The E39/C model shows a smaller sensitivity to the additional sulphuric acid particles, with respect to the other models.

The resulting ozone perturbation is presented in Fig. 14. It is important to note that for ozone the effects related to the transport of $\mathrm{NO}_{\mathrm{x}}$ and $\mathrm{H}_{2} \mathrm{O}$ throughout the stratosphere are important, together with the transport of ozone itself (Rogers et al., 2002). With this in mind, it can be seen that the NH mid-latitude ozone profile changes (S6-S4) are consistent between the four models. The two models with a good vertical resolution of the whole stratosphere (SLIMCAT, ULAQ-CTM) predict a mid-upper stratospheric $\mathrm{O}_{3}$ depletion of the order of $0.2-0.5 \%$. This mainly results from the $\mathrm{HO}_{x}$ increase discussed in Fig. 12 and the upward transport of $\mathrm{NO}_{\mathrm{x}}$ emissions, the latter being more efficient in SLIMCAT (Rogers et al., 2002).

The calculated globally averaged $\mathrm{O}_{3}$ column change ranges between -0.08 and -0.75 Dobson Units. The variability of the modeled ozone perturbation (S6-S4) is the reason for the associated calculated range of RF reported in Fig. $10\left(-0.3\right.$ to $\left.-4.3 \mathrm{~mW} / \mathrm{m}^{2}\right)$.

A comparison of the inter-model consistency with regard to the chemical $\mathrm{O}_{3}$ destruction in the HSCT emission region is made in Fig. 15. Here the annually averaged vertical profiles of $\mathrm{O}_{3}$ loss rates at $45^{\circ} \mathrm{N}$ are compared in the pure subsonic case $\mathrm{S} 4$ for SLIMCAT and ULAQ-CTM. The comparison is made between 15 and $25 \mathrm{~km}$, the region of the majority of HSCT emissions. The two models show a high level of consistency (except for a higher $\mathrm{HO}_{\mathrm{x}}$ loss in ULAQCTM). This confirms that baseline $\mathrm{O}_{3}$ precursors and chemical rates adopted in these models are very similar. The reason for different responses of globally integrated $\mathrm{O}_{3}$ to HSCT emissions is therefore due to inter-model differences in largescale transport. This will produce significant changes in the efficiency of $\mathrm{NO}_{\mathrm{x}}$ removal from the main emission region (i.e. $\mathrm{NH}$ mid-latitude in the lower stratosphere) into the midupper tropical stratosphere, where the largest absolute $\mathrm{O}_{3}$ perturbation occurs.

\section{Conclusions}

In this study we have shown results for four independent chemical-transport models used to assess the impact of a future supersonic aircraft fleet on the chemical composition of the stratosphere. The aim of the work presented was to specifically examine the potential climatic impact of aerosol particles, directly injected by the aircraft or formed after oxidation of gaseous precursors (namely $\mathrm{SO}_{2}$ ). The climate impact is quantified in terms of the radiative forcing metric. For the aerosols we have calculated both the direct forcing (i.e. scattering and absorption of incoming solar radiation) and indirect forcing produced by changes in chemical species (i.e. $\mathrm{O}_{3}$ ) affected by heterogeneous chemical processes on 
the surfaceof aerosol particles. Other indirect processes (for example potential aerosol feedback on the formation of cirrus ice particles in the upper troposphere) have not been taken into account in this study.

The direct aerosol RF is calculated using the radiative code of ULAQ-GCM and the aerosol formation/growth modeling codes of ULAQ-CTM. The chemical feedback of sulphuric acid aerosols is rather complex to assess, since although the direct impact is on the $\mathrm{NO}_{\mathrm{x}} / \mathrm{HNO}_{3}$ ratio, they also indirectly affect the concentrations of $\mathrm{HO}_{x}, \mathrm{Cl}_{x}, \mathrm{Br}_{x}$ and $\mathrm{O}_{3}$, the latter being a key species for the atmospheric climate system. The four ACMs appear consistent in predicting the ozone perturbation due to a HSCT fleet in 2050, with a globally averaged column change, ranging between -0.08 and -0.75 DU. All models, except E39/C, predict an ozone decrease not only above $20 \mathrm{~km}$ altitude, but also in the lower stratosphere (ranging between $-0.2 \%$ and $-1 \%$ ). The calculated radiative forcing is found to range between -0.3 and $-4.3 \mathrm{~mW} / \mathrm{m}^{2}$.

From this modeling study, the impact of supersonic aircraft on sulphuric acid aerosol and BC mass burdens is calculated at 53 and $1.5 \mu \mathrm{g} / \mathrm{m}^{2}$, respectively, with a direct radiative forcing of -11.4 and $4.6 \mathrm{~mW} / \mathrm{m}^{2}$ respectively. The indirect aerosol RF due to ozone changes via perturbations in the heterogeneous chemistry is highly variable among the models, and depends on the $\mathrm{NO}_{\mathrm{x}}$ removal efficiency from the aircraft emission region by large scale transport $\left(-6.6 \mathrm{~mW} / \mathrm{m}^{2}\right.$ in ULAQ-GCM up to $+1.8 \mathrm{~mW} / \mathrm{m}^{2}$ in SLIMCAT). As calculated with the ULAQ-GCM, the aerosol indirect chemical $\mathrm{RF}$ is comparable with the direct RF, both in magnitude and sign. The total net particle-related RF is also found to be the largest component of RF from supersonic aircraft after that of stratospheric water vapour.

Acknowledgements. We acknowledge the EC for providing funds for this work, under contract EVK2-CT2001-00103 (SCENIC). More information on SCENIC related work can be found on http://www-scenic.ch.cam.ac.uk/ and in the SCENIC (2005) final report. We also acknowledge use of SAGE-II and HALOE data for model validation of aerosol products.

Edited by: B. Kärcher

\section{References}

Andrews, D. G., Holton, J. R., and Leovy, C. B.: Middle atmosphere Dynamics, Academic Press, 490 pp., 1987.

Baughcum, S. L. and Henderson, S. C.: Aircraft Emission Scenarios Projected in Year 2015 for the NASA Technology Concept Aircraft (TCA) High Speed Civil Transport Universal Airline Network. NASA-CR-1998-207635, National Aeronautics and Space Administration, Langley Research Center, Hampton, VA, USA, 42 pp., 1998.

Berntsen, T. and Isaksen, I. S. A.: A global 3-D chemical transport model for the troposphere, 1, model description and co and ozone results, J. Geophys. Res., 102, 21 239-21 280, 1997.
Brian, H. S. and Prather, M. J.: Fast-J2: Accurate simulation of stratospheric photolysis in global chemical models, J. Atmos. Chem., 41, 3, 281-296, doi:10.1023/A:1014980619462, 2002.

Brunner, D., Staehelin, J., Rogers, H., Köhler, M., Pyle, J., Hauglustaine, D., Jourdain, L., Berntsen, T. K., Gauss, M., Meijer, I. I. E., van Velthoven, P., Pitari, G., Mancini, E., Grewe, V., and Sausen, R.: An evaluation of the performance of chemistry transport models by comparison with research aircraft observations. part 1: Concepts and overall model performance, Atmos. Chem. Phys., 3, 1609-1631, 2003, http://www.atmos-chem-phys.net/3/1609/2003/.

Brunner, D., Staehelin, J., Rogers, H., Köhler, M., Pyle, J., Hauglustaine, D., Jourdain, L., Berntsen, T. K., Gauss, M., Meijer, I. I. E., van Velthoven, P., Pitari, G., Mancini, E., Grewe, V., and Sausen, R.: An evaluation of the performance of chemistry transport models - Part 2: Detailed comparison with two selected campaigns, Atmos. Chem. Phys., 5, 107-129, 2005, http://www.atmos-chem-phys.net/5/107/2005/.

Chipperfield, M., Blom, C., Glatthor, N., Höpfner, M., Gulde, T., Piesch, C., and Simon, P.: Variability of clono 2 in the arctic polar vortex: Comparison of transall mipas measurements and 3d model results, J. Geophys. Res., 100, 9115-9129, 1995.

Chipperfield, M., Santee, M., Froidevaux, L., Manney, G., Read, W., Waters, J., Roche, A., and Russell, J.: Analysis of uars data in the southern polar vortex in September 1992 using a chemical transport model, J. Geophys. Res., 101, 18 861-18 881, 1996.

Chipperfield, M. and J. Pyle: Model sensitivity studies of arctic ozone depletion, J. Geophys. Res., 103, 28 389-28 403, 1998.

Dameris, M., Grewe, V., Ponater, M., Deckert, R., Eyring, V., Mager, F., Matthes, S., Schnadt, C., Stenke, A., Steil, B., Brül, C., and Giorgetta, M. A.: Long-term changes and variability in a transient simulation witha chemistry-climate model employing realistic forcing, Atmos. Chem. Phys., 5, 2121-2145, 2005, http://www.atmos-chem-phys.net/5/2121/2005/.

Dessens O., Rogers, H. L., and Pyle, J. A.: A change in the calculated impact of supersonic aircraft NOx emissions on the atmosphere, Aeronaut. J., 111, 311-314, 2007.

ECMWF: IFS documentation CY28R1, The ECMWF Integrated Forecast System (IFS), 2004.

Foster, P. M. F. and Shine, K. P.: Radiative forcing and temperature trends from stratospheric ozone changes, J. Geophys. Res., 102, 10 841-10 857, 1997.

Gauss, M., Isaksen, I. S. A., Wong, S., and Wang, W.: Impact of $\mathrm{H}_{2} \mathrm{O}$ emissions from cryoplanes and kerosene aircraft on the atmosphere, J. Geophys. Res., 108, 4304, doi:10.1029/2002JD002623, 2003.

Gauss, M., Isaksen, I. S. A., Lee, D. S., and Søvde, O. A.: Impact of aircraft $\mathrm{NO}_{X}$ emissions on the atmosphere - tradeoffs to reduce the impact, Atmos. Chem. Phys., 6, 1529-1548, 2006, http://www.atmos-chem-phys.net/6/1529/2006/.

Grewe, V., Dameris, M., Fichter, C., and Sausen, R.: Part 1: Interactively coupled climate-chemistry simulations and sensitivities to climate-chemistry feedback, lightning and model resolution, Meteorol. Z., 3, 177-186, 2002.

Grewe, V., Stenke, A., Ponater, M., Sausen, R., Pitari, G., Iachetti, D., Rogers, H., Dessens, O., Pyle, J., Isaksen, I. S. A., Gulstad, L., Søvde, O. A., Marizy, C., and Pascullo, E.: Climate impact of supersonic air traffic: an approach to optimize a potential future supersonic fleet, Results from EU-project SCENIC, Atmos. 
Chem. Phys., 7, 5129-5145, 2007,

http://www.atmos-chem-phys.net/7/5129/2007/.

Grewe, V. and Stenke, A.: A strategy for climate evaluation of aircraft technology: an efficient climate impact assessment tool AirClim, Atmos. Chem. Phys. Discuss., 7, 12 185-12 229, 2007.

Hansen, J., Sato, M., and Ruedy, R.: Radiative forcing and climate response, J. Geophys. Res., 102, 6831-6864, 1997.

Hein, R., Dameris, M., Schnadt, C., Land, C., Grewe, V., Köhler, M., Ponater, I. M., Sausen, R., Steil, B., Landgraf, J., and Bürhl, C.: Results of an interactively coupled atmospheric chemistry general circulation model: Comparison with observations, Ann. Geophys., 19, 435-457, 2001,

http://www.ann-geophys.net/19/435/2001/.

Hesstvedt, E., Hov, O., and Isaksen, I. S. A.: Quasi steady-state approximation in air pollution modelling: Comparison of two numerical schemes for oxidant prediction, Int. J. Chem. Kinet., 10, 971-994, 1978.

Holtslag, A. A. M., DrBruijn, E. I. F., and Pan, H.-L.: A high resolution air mass transformation model for short-range weather forecasting, Mon. Weather Rev., 118, 1561-1575, 1990.

Houghton, J. T., Ding, Y., Griggs, D. J., et al.: IPCC, Climate Change: The Scientific Basis, Contribution of Working Group I to the Third Assessment Report of the Intergovernmental Panel of Climate Change, Cambridge University Press, 881 pp., 2001.

Isaksen, I. S. A., Rognerud, B., Stordal, F., Coffey, M. T., and Mankin, W. G.: Studies of arctic stratospheric ozone in a 2-D model including some effects of zonal asymmetries, Geophys. Res. Lett., 17, 557-560, 1990.

JPL: Chemical kinetics and photochemical data for use in stratospheric modelling, JPL publ., 97-4, 266 pp., Pasadena, California, USA, 1997.

JPL: Chemical kinetics and photochemical data for use in stratospheric modeling, Eval. 13, JPL Publ. 00-3, 74 pp., Jet Propul. Lab., Pasadena, California, USA, 2000.

Kent, G. S. and McCormick, M. P.: SAGE and SAM II measurements of global stratospheric aerosol optical depth and mass loading, J. Geophys. Res., 89, 5303-5314, 1984.

Kinne, S., Schulz, M., Textor, C., Guibert, S., Balkanski, Y., Bauer, S. E., Berntsen, T., Berglen, T. F., Boucher, O., Chin, M., Collins, W., Dentener, F., Diehl, T., Easter, R., Feichter, J., Fillmore D., Ghan, S., Ginoux, P., Gong, S., Grini, A., Hendricks, J., Herzog, M., Horowitz, L., Isaksen, I., Iversen, T., Kirkevàg, A., Kloster, S., Koch, D., Kristjansson, J. E., Krol, M., Lauer, A., Lamarque, J. F., Lesins, G., Liu, X., Lohmann, U., Montanaro, V., Myhre, G., Penner, J., Pitari, G., Reddy, S., Seland, O., Stier, P., Takemura, T., and Tie, X.: An AeroCom initial assessment optical properties in aerosol component modules of global models, Atmos. Chem. Phys., 6, 1815-1834, 2006,

http://www.atmos-chem-phys.net/6/1815/2006/.

Lacis, A. and Hansen, J. E.: A parameterization for the absorption of solar radiation in the Hearths atmosphere, J. Atmos. Sci., 31, 118-133, 1974.

Lacis, A., Hansen, J., and Sato, M.: Climate forcing by stratospheric aerosols, Geophys. Res. Lett., 19, 1607-1610, 1992.

Land, C., Feichter, J., and Sausen, R.: Impact of the vertical resolution on the transport of passive tracers in the echam 4 model, Tellus B, 54, 344-360, 2002.

Park, J. H., Ko, M. K. W., Jackman, C. H., et al. : Model and Measurements intercomparison II, NASA/TM-1999-209554, 494 pp., 1999.

Penner, J. E., Lister, D. H., Griggs, D. J. et al.:IPCC, Special report on aviation and the global atmosphere, Cambridge Univ. Press, Cambridge, 373 pp., 1999.

Pitari, G., Rizi, V., Ricciardulli, L., and Visconti, G.,: High speed civil transport impact: role of sulphate, nitric and trihydrate, and ice aerosol studied with a two-dimensional model including aerosol physics, J. Geophys. Res., 98, 23 141-23 164, 1993.

Pitari, G., and Mancini, E.: Climatic impact of future supersonic aircraft: role of water vapour and ozone feedback on circulation, Phys. Chem. of Earth PT C, 26/8, 571-576, 2001.

Pitari, G., Mancini, E., Bregman, A., Rogers, H. L., Sundet, J. K., Grewe, V., and Dessens, O.: Sulphate particles from subsonic aviation: Impact on upper tropospheric and lower stratospheric ozone, Phys. Chem. Earth PT C, 26/8, 563-569, 2001.

Pitari, G., Mancini, E., Rizi, V., and Shindell, D. T.: Impact of future climate and emission changes on stratospheric aerosols and ozone. J. Atmos. Sci., 59, 414-440, 2002.

Pitari, G., Mancini, E., Rogers, H. L., Dessens, O., Isaksen, I. S. A., and Rognerud, B.: A 3-D model intercomparison of the effects of future Supersonic aircraft on the chemical composition of the stratosphere, Proceedings of the 2003 AAC-Conference, Friedrichshafen, Germany, 166-172, 2004.

Prather, M. J., Wesoky, H. L., Miake-Lye, R.C., et al. Eds.: The atmospheric effects of stratospheric aircraft: A first program report, NASA Ref. Publ. 1272, 1992.

Prather, M.: Numerical advection by conservation of second-order moments. J. Geophys. Res., 91, 6671-6681, 1986.

Pyle, J., Chipperfield, M., Kilbane-Dawe, I., Lee, A, Stimpe, R., Kohn, D., Renger, W., and Waters, J.: Early modelling results from the sesame and ASHOE campaigns, Faraday Discuss, 100, 371-387, 1995.

Ramanathan, V.: Radiative transfer within the Earths troposphere and stratosphere: A simplified radiative convective model, J. Atmos. Sci., 33, 1330-1346, 1976.

Ramanathan, V., Pitcher, E. J., Malone, R. C., and Blackmon, M. L.: The response of a spectral general circulation model to refinements in radiative processes, J. Atmos. Sci., 40, 605-630, 1983.

Reithmeier, C. and Sausen, R.: ATTILA - Atmospheric Tracer transport in a Lagrangian Model, TellusB, 54(3), 278-299, 2002.

Rogers, H. L., Chipperfield, M., Bekki, S., and Pyle, J.: The effects of future supersonic aircraft on stratospheric chemistry modelled with varying meteorology. J. Geophys. Res., 105, 29 359-29 369, 2000.

Rogers, H. L., Teyssedre, H., Pitari, G., Grewe, V., van Velthoven, P., and Sundet, J.: Model intercomparison of the transport of aircraft-like emissions from sub- and supersonic aircraft, Meteorol. Z., 11, 151-159, 2002.

Rummukainen, M., Isaksen, I. S. A., Rognerud, B., and Stordal, F.: A global model tool for three-dimensional multiyear stratospheric chemistry simulations: Model description and first results, J. Geophys. Res., 104, 26 437-26 456, 1990.

Rummukainen, M.: Modeling stratospheric chemistry in a global three-dimensional chemical transport model, sctm-1, Model development, Finnish Meteorological Institute Contributions, 19, p. 206, 1996.

SCENIC: Scenario of aircraft emissions and impact studies on chemistry and climate, EU contract EVK2-2001-00103 (2002- 
2005), final report, 2005.

Schulz, M., Textor, C., Kinne, S., Balkanski, Y., Bauer, S., Berntsen, T., Berglen, T., Boucher, O., Dentener, F., Guibert, S., Isaksen, I. S. A., Iversen, T., Koch, D., Kirkevȧg, A., Liu, X., Montanaro, V., Myhre, G., Penner, J. E., Pitari, G., Reddy, S., Seland, Ø., Stier, P., and Takemura, T.: Radiative forcing by aerosols as derived from the AeroCom present-day and pre-industrial simulations, Atmos. Chem. Phys., 6, 5225-5246, 2006 ,

http://www.atmos-chem-phys.net/6/5225/2006/.

Søvde, O. A., Gauss, M., Smyshlyaev, S. P., and Isaksen, I. S. A.: Evaluation of the chemical transport model Oslo CTM2 with focus on arctic winter ozone depletion, J. Geophys. Res., 113, D09304, doi:10.1029/2007JD009240, 2008.

Steil, B., Dameris, M., Brühl, C., Crutzen, P., Grewe, V., Ponater, M., and Sausen, R.: Development of a chemistry module for GCMs: first results of a multiannual integration, Ann. Geophys., 16, 205-228, 1998, http://www.ann-geophys.net/16/205/1998/.

Stenke, A., Grewe, V., and Ponater, M.: Lagrangian transport of water vapor and cloud water in the ECHAM GCM and its impact on the cold bias, Clim. Dynam., doi:10.1007/S00382-007-03475, 2007.

Stenke, A., Grewe, V., and Pechtl, S.: Do supersonic aircraft avoid contrails?, Atmos. Chem. Phys., 8, 955-967, 2008, http://www.atmos-chem-phys.net/8/955/2008/.

Stordal, F., Isaksen, I., and Horntvedt, K.: Adiabatic circulation two-dimensional model with photochemistry: Simulations of ozone and long-lived tracers with surface sources, J. Geophys. Res., 90, 5757-5776, 1985.

Sundet, J. K.: Model studies with a 3-D global CTM using ECMWF data, Ph.D. thesis, University of Oslo Norway, 1997.

Textor, C., Schulz, M., Guibert, S., Kinne, S., Balkanski, Y., Bauer, S., Berntsen, T., Berglen, T., Boucher, O., Chin, M., Dentener, F., Diehl, T., Easter, R., Feichter, H., Fillmore, D., Ghan, S., Ginoux, P., Gong, S., Grini, A., Hendricks, J., Horowitz, L., Huang, P., Isaksen, I., Iversen, I., Kloster, S., Koch, D., Kirkevảg, A., Kristjansson, J. E., Krol, M., Lauer, A., Lamarque, J. F., Liu, X., Montanaro, V., Myhre, G., Penner, J., Pitari, G., Reddy, S., Seland, Ø., Stier, P., Takemura, T., and Tie, X.: Analysis and quantification of the diversities of aerosol life cycles within AeroCom, Atmos. Chem. Phys., 6, 1777-1813, 2006,

http://www.atmos-chem-phys.net/6/1777/2006/.
Textor, C., Schulz, M., Guibert, S., Kinne, S., Balkanski, Y., Bauer, S., Berntsen, T., Berglen, T., Boucher, O., Chin, M., Dentener, F., Diehl, T., Feichter, J., Fillmore, D., Ginoux, P., Gong, S., Grini, A., Hendricks, J., Horowitz, H., Huang, P., Isaksen, I. S. A., Iversen, T., Kloster, S., Koch, D., Kirkevảg, A., Kristjansson, J. E., Krol, M., Lauer, A., Lamarque, J. F., Liu, X., Montanaro, V., Myhre, G., Penner, J. E., Pitari, G., Reddy, M. S., Seland, Ø., Stier, P., Takemura, T., and Tie, X.: The effect of harmonized emissions on aerosol properties in global models an AeroCom experiment, Atmos. Chem. Phys., 7, 4489-4501, 2007, http://www.atmos-chem-phys.net/7/4489/2007/.

Tiedtke, M. A.: Comprehensive mass UX scheme for cumulus parameterization on large scale models, Mon. Weather Rev., 117, 1779-1800, 1989.

TRADEOFF: Tradeoff aircraft emissions: Contributions of various climate compounds to changes in composition and radiative forcing - tradeoff to reduce atmospheric impact, EU-contract EVK2CT-1999-0030 (2000-2003), final report, 2003.

Vardavas, I. M. and Carver, J. H.: Solar and terrestrial parameterizations for radiative-convective models, Planet. Space Sci., 32, 1307-1325, 1984.

Weisenstein, D., Bekki, S., Pitari, G., Timreck, C., and Mills, M.: WCRP/SPARC scientific assessment of stratospheric aerosol properties, in: Modeling of stratospheric aerosols, Chapter 6: edited by: Thomason, L. and Peter, T., WCRP-124, WMO/TD1295, SPARC report no. 4, 2006.

Williamson, D. L. and Rasch, P. J.: Water vapour transport in the NCAR CCM2, Tellus, 46A, 34-51, 1993.

WMO: Atmospheric Ozone-1985, WMO-Global Ozone Res. Monit. Proj. Rep. 16, Vol.1, World Meteorological Organization, Geneva, Switzerland, 1985.

Wuebbles, D. J., Dutta, M., Patten, K. O., and Baughcum, S. L.: Parametric Study of Potential Effects of Aircraft Emissions on Stratospheric O3, Proceedings of the AAC-Conference, 140-144, Friedrichshafen, Germany, 2003. 